\title{
Facile synthesis of cubic cuprous oxide for electrochemical reduction of carbon dioxide
}

\author{
Juqin Zeng ${ }^{1, *}$ (1), Micaela Castellino ${ }^{2}$ (D), Katarzyna Bejtka ${ }^{1}$ (D), Adriano Sacco ${ }^{1}$ (D), \\ Gaia Di Martino ${ }^{1,2}$, M. Amin Farkhondehfal $^{1}$ (D), Angelica Chiodoni ${ }^{1}$ (D), Simelys Hernández ${ }^{1,2}$ (D), \\ and Candido F. Pirri ${ }^{1,2}$ (B) \\ ${ }^{1}$ Center for Sustainable Future Technologies @POLITO, Istituto Italiano di Tecnologia, Via Livorno 60, 10144 Turin, Italy \\ ${ }^{2}$ Department of Applied Science and Technology, Politecnico di Torino, C.so Duca degli Abruzzi 24, 10129 Turin, Italy
}

Received: 19 April 2020

Accepted: 1 September 2020

Published online:

18 September 2020

(C) The Author(s) 2020

\begin{abstract}
High level of atmospheric carbon dioxide $\left(\mathrm{CO}_{2}\right)$ concentration is considered one of the main causes of global warming. Electrochemical conversion of $\mathrm{CO}_{2}$ into valuable chemicals and fuels has promising potential to be implemented into practical and sustainable devices. In order to efficiently realize this strategy, one of the biggest efforts has been focused on the design of catalysts which are inexpensive, active and selective and can be produced through green and upscalable routes. In this work, copper-based materials are simply synthesized via microwave-assisted process and carefully characterized by physical/chemical/electrochemical techniques. Nanoparticle with a cupric oxide $(\mathrm{CuO})$ surface as well as various cuprous oxide $\left(\mathrm{Cu}_{2} \mathrm{O}\right)$ cubes with different sizes is obtained and used for the $\mathrm{CO}_{2}$ reduction reaction. It is observed that the $\mathrm{Cu}_{2} \mathrm{O}$-derived electrodes show enhanced activity and carbon monoxide (CO) selectivity compared to the $\mathrm{CuO}$-derived one. Among various $\mathrm{Cu}_{2} \mathrm{O}$ catalysts, the one with the smallest cubes leads to the best $\mathrm{CO}$ selectivity of the electrode, attributed to a higher electrochemically active surface area. Under applied potentials, all $\mathrm{Cu}_{2} \mathrm{O}$ cubes undergo structural and morphological modification, even though the cubic shape is retained. The nanoclusters formed during the material evolution offer abundant and active reaction sites, leading to the high performance of the $\mathrm{Cu}_{2} \mathrm{O}$-derived electrodes.
\end{abstract}

Handling Editor: Kyle Brinkman.

Address correspondence to E-mail: juqin.zeng@iit.it 


\section{GRAPHIC ABSTRACT}

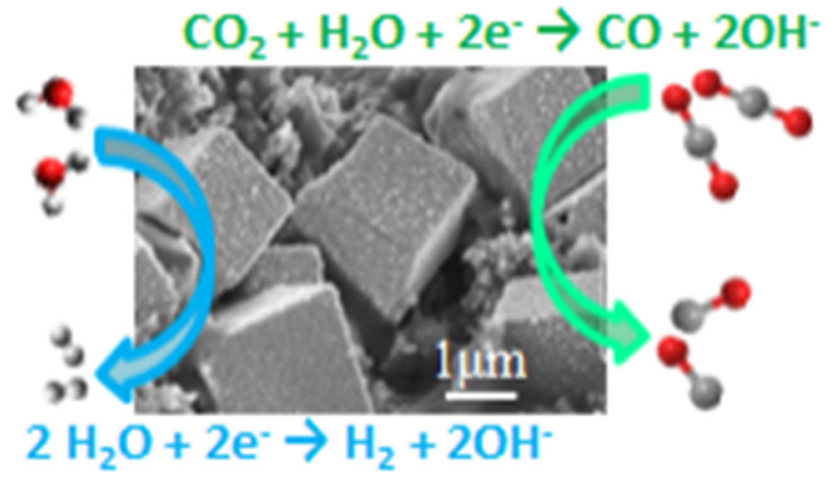

\section{Introduction}

The global energy supply based on fossil fuels has reached an unprecedented scale leading to excess anthropogenic $\mathrm{CO}_{2}$ emission. $\mathrm{CO}_{2}$ accumulates in the atmosphere, and its concentration has surpassed $400 \mathrm{ppm}$ in 2016, much higher than the $270 \mathrm{ppm}$ during the pre-industrial era [1]. As a well-known greenhouse gas, accumulated $\mathrm{CO}_{2}$ traps more infrared radiation, breaking the energy balance on the earth's surface. Although atmospheric $\mathrm{CO}_{2}$ concentration can be balanced by natural absorption (by the ocean and vegetation), the continuous increase in $\mathrm{CO}_{2}$ concentration indicates that anthropogenic $\mathrm{CO}_{2}$ emission has upset the natural balance, thus leading to global warming and climate change. Using $\mathrm{CO}_{2}$ as feedstock to produce valuable carbon-based chemicals is considered to be a feasible approach to close the carbon cycle and mitigate the climate change. Many strategies have been developed for $\mathrm{CO}_{2}$ valorization, including thermochemical, photochemical, electrochemical and biological approaches [2-5]. Among these methods, electrochemical $\mathrm{CO}_{2}$ conversion is of particular interest, since it can be carried out under ambient conditions and $\mathrm{H}_{2} \mathrm{O}$ could be the only required feedstock except $\mathrm{CO}_{2}$. The reaction rate and the type of products can be possibly controlled by tuning the external bias and the employed electrocatalysts [1]. In addition, by using the electricity generated from renewable energy, it is possible to achieve a sustainable route for energy storage and conversion [6]. However, the carbon dioxide reduction reaction $\left(\mathrm{CO}_{2} \mathrm{RR}\right)$ involves several proton-assisted multiple-electron-transfer processes with similar standard potentials (V versus the reversible hydrogen electrode (RHE), Reactions R1-R5) [7-9]. Moreover, $\mathrm{H}_{2}$ evolution is the competing reaction in aqueous solution (Reaction R6). Therefore, it is a challenge to control the selectivity of the $\mathrm{CO}_{2} \mathrm{RR}$ from the thermodynamic view:

$$
\begin{aligned}
& \mathrm{CO}_{2}+2 \mathrm{H}^{+}+2 \mathrm{e}^{-} \rightarrow \mathrm{CO}+\mathrm{H}_{2} \mathrm{O} \quad E=-0.105 \mathrm{~V} \\
& \mathrm{CO}_{2}+2 \mathrm{H}^{+}+2 \mathrm{e}^{-} \rightarrow \mathrm{HCOOH} \quad E=-0.169 \mathrm{~V} \\
& \mathrm{CO}_{2}+8 \mathrm{H}^{+}+8 \mathrm{e}^{-} \rightarrow \mathrm{CH}_{4}+2 \mathrm{H}_{2} \mathrm{O} \quad E=+0.169 \mathrm{~V} 2 \\
& 2 \mathrm{CO}_{2}+12 \mathrm{H}^{+}+12 \mathrm{e}^{-} \rightarrow \mathrm{C}_{2} \mathrm{H}_{4}+4 \mathrm{H}_{2} \mathrm{O} \\
& E=+0.079 \mathrm{~V} \\
& \mathrm{CO}_{2}+6 \mathrm{H}^{+}+6 \mathrm{e}^{-} \rightarrow \mathrm{CH}_{3} \mathrm{OH}+\mathrm{H}_{2} \mathrm{O} \quad E=+0.017 \mathrm{~V} \\
& \\
& 2 \mathrm{H}^{+}+2 \mathrm{e}^{-} \rightarrow \mathrm{H}_{2} \quad E=0.000 \mathrm{~V}
\end{aligned}
$$

From the kinetic point of view, it is even more challenging to form chemical bonds for the complex and energetic molecule products [10]. Transferring one electron to the adsorbed $\mathrm{CO}_{2}$ molecule to activate it (generating the radical $\mathrm{CO}_{2}{ }^{*-}$ ) is believed to be the rate-determining step of the $\mathrm{CO}_{2} \mathrm{RR}$ on transition metal-based catalysts because of the high activation barrier needed for this step [11]. Consequently, much more negative potentials than the standard ones are 
needed to drive the $\mathrm{CO}_{2} \mathrm{RR}$. Therefore, an appropriately designed catalyst is essential in order to activate the $\mathrm{CO}_{2}$ molecules. Once $\mathrm{CO}_{2}{ }^{*-}$ forms on the catalyst's surface, its reactivity in this state controls the distribution of final products. Both early and later studies [12-14] of electrochemical $\mathrm{CO}_{2} \mathrm{RR}$ on various metal-based electrodes found that the radical $\mathrm{CO}_{2}{ }^{*-}$ interacts with the surface of the catalyst in different ways, depending on the intrinsic electronic surface's properties of the material. Hence, a suitable catalyst is necessary in order to selectively drive the $\mathrm{CO}_{2} \mathrm{RR}$ and to obtain a specific product.

Syngas, a mixture of $\mathrm{H}_{2}$ and $\mathrm{CO}$, can be used as an energy carrier since it can be transformed in liquid fuels through Fischer-Tropsch process or converted into other useful products such as ammonia and alcohols $[15,16]$. Nowadays, syngas is mainly produced from natural gas by steam reforming, a process that requires high temperature [15]. For this reason, much effort has been devoted to developing an electrochemical process that requires less energy input, enables utilization of renewable energy and allows an easier control of $\mathrm{H}_{2} / \mathrm{CO}$ ratio. Even though silver $(\mathrm{Ag})$ and gold $(\mathrm{Au})$ are the most intensively studied electrocatalysts for efficiently and selectively reducing $\mathrm{CO}_{2}$ to $\mathrm{CO}$ [16], due to their high price and deficiency, many studies have been focused on other non-precious metals such as copper $(\mathrm{Cu})$, zinc $(\mathrm{Zn})$, tin (Sn) and bismuth (Bi) [17-20]. Due to its unique feature and high electric conductivity, $\mathrm{Cu}$ became the most studied element and the investigations mainly focus on size and shape effect, copper composites, copper complexes and copper alloys [21-27]. Our recent work revealed that the initial oxidation state of $\mathrm{Cu}$ on the surface significantly influences the performance of the catalysts in the $\mathrm{CO}_{2} \mathrm{RR}$ [28]. A high content of $\mathrm{Cu}_{2} \mathrm{O}$ on the as-prepared material surface improves the selectivity toward $\mathrm{CO}$, while the $\mathrm{CuO}$ performs badly.

The present work mainly focuses on $\mathrm{Cu}_{2} \mathrm{O}$ cubes with various sizes. We synthesized the $\mathrm{Cu}$-based materials through a green route with microwave irradiation, using copper acetate as $\mathrm{Cu}$ precursor and ethylene glycol as solvent and reducing agent. Under the microwave radiation at $180{ }^{\circ} \mathrm{C}, \mathrm{Cu}^{2+}$ ions were reduced, forming cubic cuprous oxide $\left(\mathrm{Cu}_{2} \mathrm{O}\right)$ particles. The addition of $\mathrm{Sn}^{4+}$ ions to the copper precursor only reduced the size of $\mathrm{Cu}_{2} \mathrm{O}$ cubes without changing the shape and oxidation state significantly, while addition of $\mathrm{Sn}^{2+}$ ions changed the oxidation state as well as the shape, resulting in irregular nanoparticle agglomerates. Various electrochemical techniques were applied to evaluate the activity and selectivity of these electrocatalysts toward the $\mathrm{CO}_{2}$ RR. It is revealed that the $\mathrm{H}_{2} / \mathrm{CO}$ ratio of syngas can be easily tuned by adopting different catalysts with variations in size, shape and oxidation state.

\section{Materials and methods}

\section{Materials}

Copper acetate $\left(\mathrm{Cu}\left(\mathrm{CH}_{3} \mathrm{COO}\right)_{2}, 99.9 \%\right)$, tin(II) chloride dihydrate $\left(\mathrm{SnCl}_{2} \cdot 2 \mathrm{H}_{2} \mathrm{O}, 99.9 \%\right)$, tin(IV) chloride pentahydrate $\left(\mathrm{SnCl}_{4} \cdot 5 \mathrm{H}_{2} \mathrm{O}, 98 \%\right)$, sodium hydroxide $(\mathrm{NaOH}, 98 \%)$, potassium bicarbonate $\left(\mathrm{KHCO}_{3}\right.$, $99.7 \%$ ), ethylene glycol (EG, 99.8\%), Nafion ${ }^{\circledR} 117$ solution $(5 \mathrm{wt} \%)$ and isopropanol were purchased from Sigma-Aldrich. Unless otherwise specified, all the materials were used as received.

\section{Synthesis of copper-based catalysts}

The copper-based catalysts were fabricated through a microwave-assisted solvothermal route, with $\mathrm{Cu}\left(\mathrm{CH}_{3} \mathrm{COO}\right)_{2}$ and $\mathrm{SnCl}_{2} \cdot 2 \mathrm{H}_{2} \mathrm{O}$ or $\mathrm{SnCl}_{4} \cdot 5 \mathrm{H}_{2} \mathrm{O}$ as the metal salts. The catalysts prepared with various concentrations of different salts are named as $\mathrm{Cu}(\mathrm{II}) \mathrm{Sn}(\mathrm{x}) \mathrm{y}$, where $\mathrm{x}$ indicates the valence of $\mathrm{Sn}$ ions (II or IV) and y is the weight percentage (\%) of Sn salt with respect to $\mathrm{Cu}$ one. In a typical synthesis (Scheme S1 in the Supporting Information), $900 \mathrm{mg}$ of $\mathrm{Cu}$ salt and a certain amount of $\mathrm{Sn}$ salt were dissolved in $20 \mathrm{~mL}$ of EG to form solution 1, and $1280 \mathrm{mg}$ of $\mathrm{NaOH}$ was dissolved in $24 \mathrm{~mL}$ of EG and $4 \mathrm{~mL}$ of $\mathrm{H}_{2} \mathrm{O}$ to form solution 2. Then, solution 2 was added into solution 1 drop by drop. After $10 \mathrm{~min}$ of vigorous agitation, the mixture was then transferred into a Teflon vessel (volume $100 \mathrm{~mL}$ ). The Teflon vessel was put in a microwave oven (Milestone STARTSynth, Milestone Inc., Shelton, Connecticut) and connected to pressure and temperature probes. The mixture was irradiated for $10 \mathrm{~min}$ at $180{ }^{\circ} \mathrm{C}$ (Max. $900 \mathrm{~W}$ ) and then was cooled to ambient temperature. The precipitate was separated by centrifuge and washed twice with $\mathrm{H}_{2} \mathrm{O}$ and once with ethanol. The powder sample was finally obtained by vacuum drying at $60^{\circ} \mathrm{C}$ overnight. Three catalysts, namely $\mathrm{Cu}(\mathrm{II}) \mathrm{Sn}(\mathrm{II}) 5, \mathrm{Cu}(\mathrm{II}) \mathrm{Sn}(\mathrm{IV}) 5$ and $\mathrm{Cu}(\mathrm{II}) \mathrm{Sn}(\mathrm{IV}) 10$, were 
prepared in a solution with both $\mathrm{Cu}$ and $\mathrm{Sn}$ salts as well as a $\mathrm{Cu}(\mathrm{II})$ catalyst with only $\mathrm{Cu}$ precursor.

\section{Physical/chemical characterizations}

Field emission scanning electron microscopy (FESEM, ZEISS Auriga) was used to investigate the morphology. The average size of the as-prepared catalyst was evaluated based on the FESEM images taken from different areas of TEM grid. The grids were prepared by placing on them a drop of catalyst dispersed in ethanol.

X-ray diffraction (XRD) was performed in BraggBrentano symmetric geometry by using a PANalytical X'Pert Pro instrument $(\mathrm{Cu}-\mathrm{K} \alpha$ radiation, $40 \mathrm{kV}$ and $30 \mathrm{~mA}$ ) equipped with an $\mathrm{X}^{\prime}$ Celerator detector. Transmission electron microscopy (TEM) characterization was performed with a FEI Tecnai F20ST microscope, equipped with a field emission gun operating at $200 \mathrm{kV}$. The TEM samples were prepared by placing a drop of catalyst dispersed in ethanol onto a holey carbon copper grid.

X-ray photoelectron spectroscopy (XPS) was carried out by using a PHI 5000 VersaProbe (Physical Electronics) system. The X-ray source was a monochromatic $\mathrm{Al} \mathrm{K \alpha}$ radiation $(1486.6 \mathrm{eV})$. Spectra were analyzed using Multipak 9.7 dedicated software. All core-level peak energies were referenced to $\mathrm{C} 1$ s peak at $284.5 \mathrm{eV}$, and the background contribution, in high-resolution (HR) spectra, was subtracted by means of a Shirley function.

The elemental analysis was carried out via inductively coupled plasma optical emission spectroscopy (ICP-OES), with an iCAP 7600 DUO (Thermo Fisher Scientific). The RF power of the plasma, the nebulizer gas flow, the coolant gas flow and the auxiliary gas flow were $1150 \mathrm{~W}, 0.5 \mathrm{~L} / \mathrm{min}, 12 \mathrm{~L} / \mathrm{min}$ and $0.5 \mathrm{~L} /$ min, respectively. Samples were weighted and digested in a flask with $10 \%$ of aqua regia overnight and filled up at volume with Milli-Q and filtered using a $0.45 \mu \mathrm{m}$ PTFE filter before reading them with the instrument. Ar gas was used as internal standard, and the $R^{2}$ value of the calibration for the $\mathrm{Sn}$ and $\mathrm{Cu}$ elements (189.99 $\lambda$, 324.75-224.70 $\lambda$, radial mode, respectively) was 0.999 .

\section{Preparation of electrodes}

To prepare the electrode, $10 \mathrm{mg}$ of synthesized $\mathrm{Cu}$ based catalyst $(\mathrm{Cu}(\mathrm{II}), \mathrm{Cu}(\mathrm{II}) \mathrm{Sn}(\mathrm{II}) 5, \mathrm{Cu}(\mathrm{II}) \mathrm{Sn}(\mathrm{IV}) 5$ or
$\mathrm{Cu}(\mathrm{II}) \mathrm{Sn}(\mathrm{IV}) 10), 1.0 \mathrm{mg}$ of acetylene carbon black (CB, Shawinigan Black AB50), $90 \mu \mathrm{L}$ of Nafion ${ }^{\circledR} 117$ solution and $320 \mu \mathrm{l}$ of isopropanol were well mixed and sonicated for 30 min until a uniform slurry was obtained. The slurry was then coated onto a carbon paper (GDL; SIGRACET 28BC, SGL Technologies), which is widely used for electrode fabrication [29]. The obtained electrode was dried at $60^{\circ} \mathrm{C}$ overnight to evaporate the solvents. The mass loading of $\mathrm{Cu}$ based catalyst is about $3.0 \mathrm{mg} \mathrm{cm}^{-2}$.

\section{Electrochemical tests and reduction product analysis}

Electrochemical impedance spectroscopy (EIS) measurements were performed in a three-electrode cell at room temperature with a CHI760D electrochemical workstation. The working electrode was a catalystcoated carbon paper with a geometric area of $0.25 \mathrm{~cm}^{2}$. A Pt wire was used as counter electrode, and $\mathrm{Ag} / \mathrm{AgCl}(3 \mathrm{M} \mathrm{NaCl})$ was used as reference electrode. EIS measurements were performed at various potentials from -0.2 to $-0.8 \mathrm{~V}$ vs RHE with an AC signal of $10 \mathrm{mV}$ of amplitude and $10^{-1}-10^{4} \mathrm{~Hz}$ frequency range in a $\mathrm{CO}_{2}$-saturated $0.1 \mathrm{M} \mathrm{KHCO}_{3}$ aqueous solution. Unless otherwise specified, all the potentials refer to RHE in this work.

Chronoamperometric (CA) measurements were carried out by using a CHI760D electrochemical workstation in order to examine the electrode activity (geometric current density) and analyze the products of the $\mathrm{CO}_{2} \mathrm{RR}$. The CA experiments were conducted in a custom-made two-compartment cell with a proton exchange membrane (Nafion ${ }^{\mathrm{TM}}$ Membrane N117, Sigma-Aldrich) as the separator (Scheme S2). The volume of each side was $40 \mathrm{~mL}$ with $15 \mathrm{~mL}$ of headspace. $\mathrm{Ag} / \mathrm{AgCl}(3 \mathrm{M} \mathrm{NaCl})$ was used as the reference and a $\mathrm{Pt}$ foil as the counter electrode. The working electrode was composed of a catalyst $(\mathrm{Cu}(\mathrm{II})$, $\mathrm{Cu}(\mathrm{II}) \mathrm{Sn}$ (II)5, Cu(II)Sn(IV)5 or Cu(II)Sn(IV)10)-coated carbon paper with a geometric area of $1.5 \mathrm{~cm}^{2}$. Unless specified, $0.1 \mathrm{M} \mathrm{KHCO}_{3}$ aqueous solution was used as the electrolyte. For CA experiments, the potential was corrected by compensating the ohmic potential drop, of which $85 \%$ was corrected by the instrument (iR-compensation) and $15 \%$ by manual calculation. Gas-phase products were analyzed online with a micro-gas chromatograph $\left(\mu \mathrm{GC}\right.$, Fusion ${ }^{\circledR}$, INFICON) equipped with two channels with a $10 \mathrm{~m}$ Rt-Molsieve $5 \mathrm{~A}$ column and an $8 \mathrm{~m}$ Rt-Q-Bond column, 
respectively, and micro-thermal conductivity detectors (micro-TCD). The inlet of the $\mu \mathrm{GC}$ was connected to the cathodic side of the electrochemical cell through a GENIE filter to remove the humidity from the gas. During the CA measurements, a constant $\mathrm{CO}_{2}$ flow rate of $20 \mathrm{~mL} \mathrm{~min}{ }^{-1}$ was maintained to saturate the electrolyte and to take the gaseous products to the $\mu \mathrm{GC}$. Liquid products were analyzed by a high-performance liquid chromatograph (Shimadzu Prominence HPLC) with a diode array detector (DAD) set at $269 \mathrm{~nm}$ by using a Rezex ROA $\left(300 \times 7.8 \mathrm{~mm}\right.$ ) column, with $5 \mathrm{mM} \mathrm{H}_{2} \mathrm{SO}_{4}$ (flow rate of $0.5 \mathrm{~mL} \mathrm{~min}{ }^{-1}$ ) as mobile phase. The faradaic efficiency (FE) for each product was calculated by dividing the coulombs needed to produce the actual determined amount of this product by the total coulombs consumed during a corresponding reduction period.

\section{Results and discussion}

\section{Physical and chemical characterizations}

FESEM images of the synthesized Cu-based samples are shown in Fig. $1 \mathrm{a}-\mathrm{d}$. When only $\mathrm{Cu}$ precursor is present in the solution, cubic particles with irregular surface are obtained (Fig. 1a). On the surface of the irregular walls and close to the cubes edges, some holes, with small crystals inside (tens of nanometers), are present, evidencing the polycrystalline structure within the cube. It is important to notice that these cubes do not aggregate and show a narrow size distribution, as shown in particle size distribution histogram in Fig. 1e, with an average size of $4.0 \pm 0.6 \mu \mathrm{m}$. When $\mathrm{Sn}(\mathrm{II})$ ions are added into the precursor solution, particles smaller in size, in the range of $30-300 \mathrm{~nm}$, and with less definite shape are formed, as displayed in Fig. 1b. In addition, these irregular particles tend to form agglomerates (insert in Fig. 1b), being driven by surface energy reduction [30]. Adding Sn(IV) into the precursor solution maintains the cubic shape of the particles and increases the twinned crystals (Fig. 1c-d). It can be also observed that the surface of the cubes becomes smoother with increasing the amount of Sn(IV) ions in the solution. Compared to the $\mathrm{Cu}$ (II) sample, $\mathrm{Cu}(\mathrm{II}) \mathrm{Sn}(\mathrm{IV}) 5$ and $\mathrm{Cu}(\mathrm{II}) \mathrm{Sn}(\mathrm{IV}) 10$ have significantly reduced particle sizes, which is demonstrated by the size distribution of the cubes (Fig. 1e) and further shown at a lower magnification in Fig. S1. The average cube size of the $\mathrm{Cu}(\mathrm{II}) \mathrm{Sn}(\mathrm{IV}) 10$ sample is of $1.7 \pm 0.3 \mu \mathrm{m}$, slightly smaller than that of $2.1 \pm 0.7 \mu \mathrm{m}$ of the $\mathrm{Cu}(\mathrm{II}) \mathrm{Sn}(\mathrm{IV}) 5$ sample.
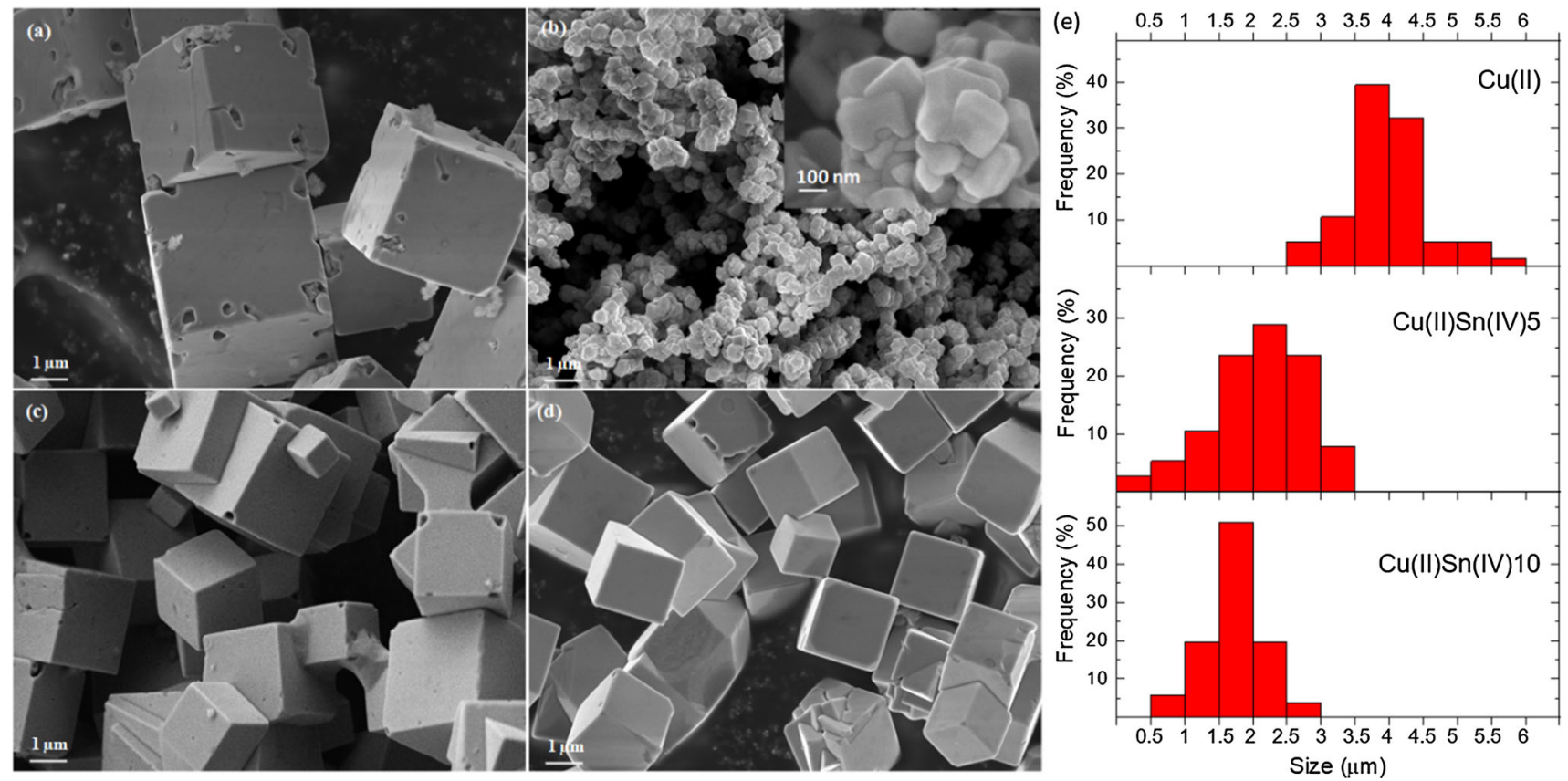

Figure 1 FESEM images of various Cu-based samples: a $\mathrm{Cu}(\mathrm{II})$; b Cu(II)Sn(II)5; c Cu(II)Sn(IV)5; d Cu(II)Sn(IV)10; and e particle size distribution calculated based on FESEM images for cube morphology samples. 


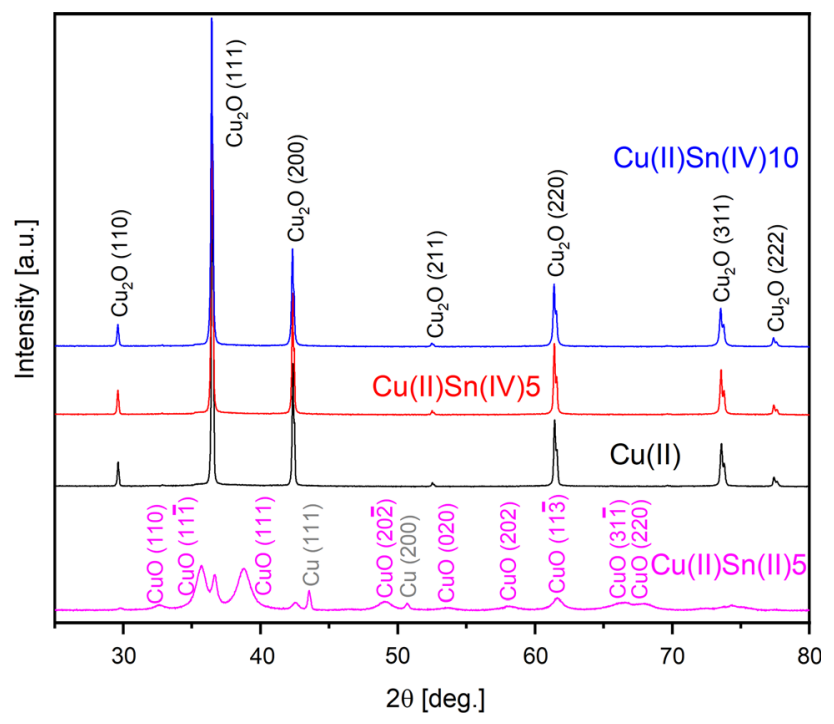

Figure 2 XRD patterns of Cu-based catalysts.

XRD patterns of $\mathrm{Cu}$-based catalysts are shown in Fig. 2. For $\mathrm{Cu}(\mathrm{II})$ sample, all peaks are associated with $\mathrm{Cu}_{2} \mathrm{O}$ and in particular to the (110), (111), (200), (211), (220), (311) and (222) planes (Cuprite, JCPDS 00-005-0667). No peaks for other crystalline phases are observed for this sample. From the XRD pattern of $\mathrm{Cu}(\mathrm{II}) \mathrm{Sn}(\mathrm{II}) 5$ sample, the peaks related to crystalline $\mathrm{CuO}$ can be well observed besides those for metallic $\mathrm{Cu}$ (Copper, JCPDS 00-004-0836) and $\mathrm{Cu}_{2} \mathrm{O}$. In contrast, addition of $\mathrm{Sn}(\mathrm{IV})$ ions in the precursor solution has no effect on the crystalline phase of the samples. The $\mathrm{Cu}(\mathrm{II}) \mathrm{Sn}(\mathrm{IV}) 5$ and $\mathrm{Cu}(\mathrm{II}) \mathrm{Sn}(\mathrm{IV}) 10$ samples show similar XRD patterns with respect to the $\mathrm{Cu}(\mathrm{II})$ one. By applying Scherrer formula [31] to the $\mathrm{Cu}_{2} \mathrm{O}$ (111) peak, we estimated that the coherent diffraction domain sizes are in the range of tens of nanometers for the $\mathrm{Cu}(\mathrm{II}), \mathrm{Cu}(\mathrm{II}) \mathrm{Sn}(\mathrm{IV}) 5$ and $\mathrm{Cu}(\mathrm{II}) \mathrm{Sn}(\mathrm{IV}) 10$ samples. This suggests that the $\mathrm{Cu}_{2} \mathrm{O}$ cubes are polycrystalline, as also partially observed from FESEM, and are composed of nanosized crystallites. Small differences are found in the diffraction peak intensity ratio of (111) and (200) planes in these samples, which are 2.5, 2.8 and 3.0 for the $\mathrm{Cu}(\mathrm{II})$, $\mathrm{Cu}(\mathrm{II}) \mathrm{Sn}(\mathrm{IV}) 5$ and $\mathrm{Cu}(\mathrm{II}) \mathrm{Sn}(\mathrm{IV}) 10$, respectively. These values are close to the value of 2.7 reported for a standard pattern of $\mathrm{Cu}_{2} \mathrm{O}$ with a cubic cuprite structure (Cuprite, JCPDS 00-005-0667). A gradual increase in peak intensity ratio of $(111) /(200)$ planes indicates a slight preferential orientation for the (111) plane. This outcome could be related to the presence of twin crystals in samples with Sn(IV) ions in the precursor solution [32].

According to the literature, the (111) and (110) surfaces are thermodynamically more stable with respect to the (100) on the clean $\mathrm{Cu}_{2} \mathrm{O}$ surfaces [33]. However, the EG molecules, as capping agents, play a crucial role during growth of $\mathrm{Cu}_{2} \mathrm{O}$. The binding energies of an EG molecule to the (110), (111) and (200) surfaces are variable, and a highest value is found for the EG to (200) surface from DFT calculations [28], pointing at the higher stability of the $\{100\}$ surfaces in the presence of EG molecules. Hence, the growth on $\{100\}$ surfaces is inhibited, while the growth along the [111] and [110] directions is unimpeded until the corresponding facets eventually disappear, explaining the appearance of cubic-shaped $\mathrm{Cu}_{2} \mathrm{O}$.

The TEM characterization was performed on a selected $\mathrm{Cu}(\mathrm{II}) \mathrm{Sn}(\mathrm{IV}) 10$ sample in order to further elucidate the structural properties at the surface. The BF-TEM in Fig. 3a shows the smooth cubes walls, which is in line with what was observed by FESEM. The TEM investigation is complicated due to the large size of the cubes, which makes them only partially transparent to the electrons. The HRTEM investigation was performed by studying only edges or corners, which were the only TEM visible parts, and is shown in Fig. 3b. The observed crystalline phase is $\mathrm{Cu}_{2} \mathrm{O}$, which is confirmed by the fast Fourier transform (shown in the inset), and this is in agreement with the XRD observation.

In order to investigate the chemical composition of the surface of various samples, XPS measurements have been performed. From the survey spectra (not reported), $\mathrm{Cu}, \mathrm{O}$ and $\mathrm{C}$ are the main elements. The presence of $\mathrm{C}$ element could be attributed to the preparation of the sample or due to adventitious carbon. Trace of $\mathrm{Sn}$ is also detected in the samples prepared with the presence of Sn ions in the precursor solution, as shown in Table S1. ICP-OES analysis has been performed on the as-prepared powder samples, and no trace of $\mathrm{Sn}$ is detected. Combining the ICP and XPS results, it is clear that $\mathrm{Sn}$ exists at a contamination level probably only on the surface. The $\mathrm{Cu} 2 p$ doublet region acquired in highresolution (HR) mode is shown in Fig. 4a. The $\mathrm{Cu}(\mathrm{II})$, $\mathrm{Cu}(\mathrm{II}) \mathrm{Sn}(\mathrm{IV}) 5$ and $\mathrm{Cu}(\mathrm{II}) \mathrm{Sn}(\mathrm{IV}) 10$ samples show a typical spectrum related to the mixed oxidation states of $\mathrm{Cu}$, including $\mathrm{Cu}^{0}, \mathrm{Cu}^{+}$and $\mathrm{Cu}^{2+}$, while the $\mathrm{Cu}(\mathrm{II}) \mathrm{Sn}(\mathrm{II}) 5$ sample displays a typical spectrum 
Figure 3 TEM

characterization of

$\mathrm{Cu}(\mathrm{II}) \mathrm{Sn}(\mathrm{IV}) 10$ sample: a BF-

TEM and $\mathbf{b}$ HRTEM with FFT in the inset.
Figure 4 XPS HR spectra for $\mathrm{Cu} 2 p$ doublets (a) and Auger CuLMM region (b).
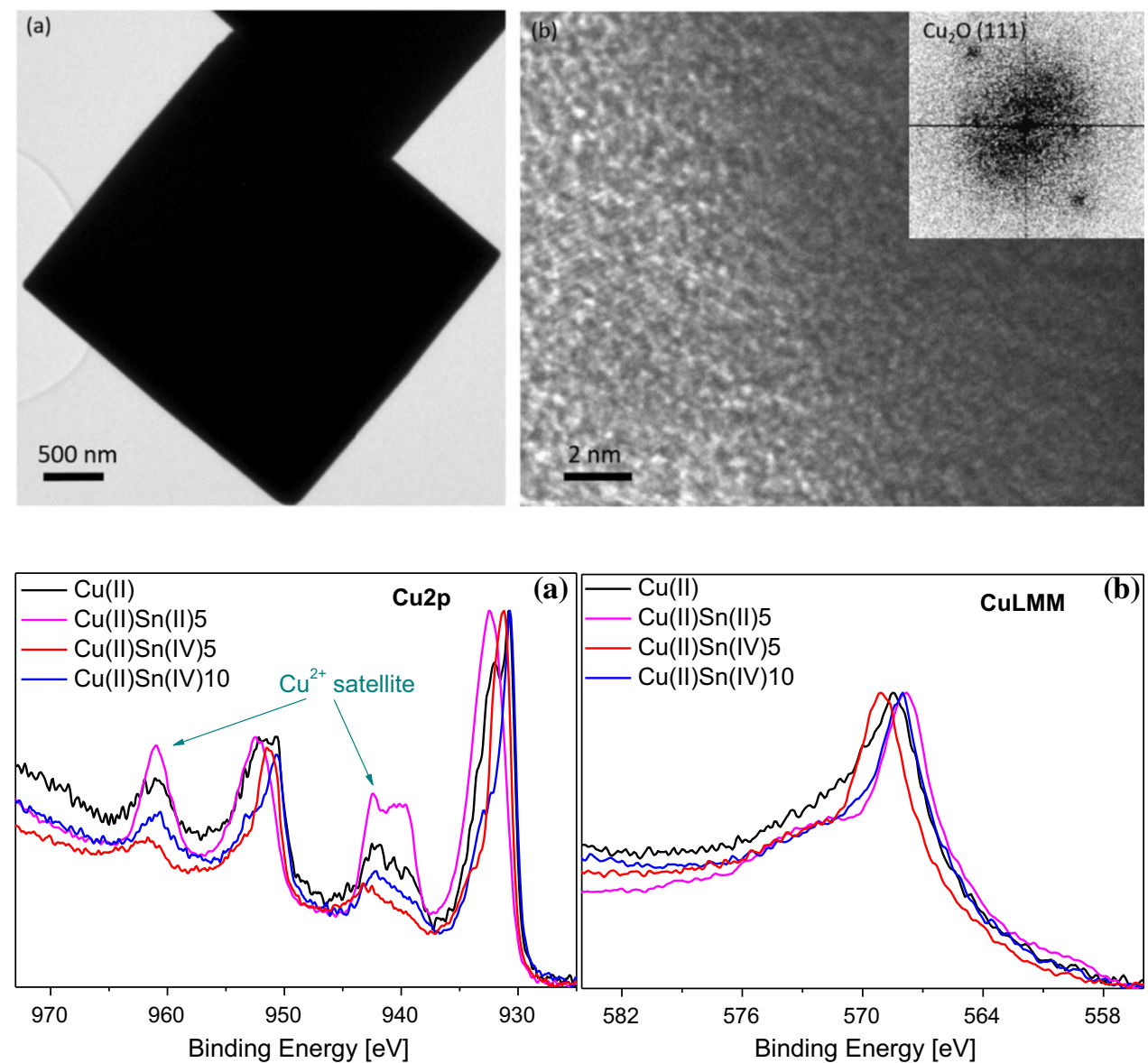

Table 1 Modified Auger parameter values for $\mathrm{Cu}$ species and relative amount of $\mathrm{Cu}(\mathrm{II})$ and $\mathrm{Cu}(0)+\mathrm{Cu}(\mathrm{I})$ for the samples

\begin{tabular}{lllc}
\hline Samples & Auger parameter $(\mathrm{eV})$ & $\mathrm{Cu}^{2+}(\%)$ & $\mathrm{Cu}^{0}+\mathrm{Cu}^{+}(\%)$ \\
\hline $\mathrm{Cu}(\mathrm{II})$ & 1848.9 & 63 & 37 \\
$\mathrm{Cu}(\mathrm{II}) \mathrm{Sn}(\mathrm{II}) 5$ & 1851.3 & 99 & 1 \\
$\mathrm{Cu}(\mathrm{II}) \mathrm{Sn}(\mathrm{IV}) 5$ & 1848.7 & 56 & 44 \\
$\mathrm{Cu}(\mathrm{II}) \mathrm{Sn}(\mathrm{IV}) 10$ & 1849.3 & 40 & 60 \\
\hline
\end{tabular}

related to only $\mathrm{Cu}^{2+}$ [34]. The $\mathrm{Cu} 2 p$ peak is complicated to be deconvoluted due to both the presence and overlapping of several satellites and shake-up peaks for each oxidation state. Hence, the Auger $\mathrm{CuL}_{3} \mathrm{M}_{4,5} \mathrm{M}_{4,5}$ region was also acquired in order to obtain more details, as shown in Fig. 4b. The Auger parameter values are calculated according to Eq. E1 and listed in Table 1:

Auger parameter $=h v-\mathrm{CuLMM}+\mathrm{Cu} 2 p_{3 / 2}$

The resulting modified Auger parameter values are approximately $1849.0 \mathrm{eV}$ for $\mathrm{Cu}(\mathrm{II}), \mathrm{Cu}(\mathrm{II}) \mathrm{Sn}(\mathrm{IV}) 5$ and $\mathrm{Cu}(\mathrm{II}) \mathrm{Sn}(\mathrm{IV}) 10$ samples, which corresponds to the average oxidation state (AOS) of $\mathrm{Cu}^{+}$[35]. The $\mathrm{Cu}(\mathrm{II}) \mathrm{Sn}(\mathrm{II}) 5$ sample has an average oxidation state of
$\mathrm{Cu}^{2+}$ on the surface, indicating that its surface is mainly composed of $\mathrm{CuO}$ with a thickness of at least 5-10 $\mathrm{nm}$ (the sensible depth for XPS). To get a deeper understanding of the relative amount of $\mathrm{Cu}$ oxidation states, we can rely on Biesinger et al. [34] study, in which they show how to evaluate the ratio between $\mathrm{Cu}^{2+}$ and $\mathrm{Cu}^{0}+\mathrm{Cu}^{+}$, by fitting $\mathrm{Cu} 2 p_{3 / 2}$ peak and its related satellite (Fig. 4). We have applied their formulas and obtained the values reported in Table 1. It is found that for samples $\mathrm{Cu}(\mathrm{II}), \mathrm{Cu}(\mathrm{II}) \mathrm{Sn}(\mathrm{IV}) 5$ and $\mathrm{Cu}(\mathrm{II}) \mathrm{Sn}(\mathrm{IV}) 10$ there is a variable mix of the two components with $40-63 \%$ of $\mathrm{Cu}^{2+}$. On the contrary sample $\mathrm{Cu}(\mathrm{II}) \mathrm{Sn}(\mathrm{II}) 5$ shows a quasi-total $\mathrm{Cu}^{2+}$ oxidation state amount (99\%), in agreement with Auger parameters results. 
Combining the above-mentioned analyses, we infer that the $\mathrm{Cu}(\mathrm{II}), \mathrm{Cu}(\mathrm{II}) \mathrm{Sn}(\mathrm{IV}) 5$ and $\mathrm{Cu}(\mathrm{II}) \mathrm{Sn}(\mathrm{IV}) 10$ cubes are mainly composed of crystalline $\mathrm{Cu}_{2} \mathrm{O}$, and their surface is made up by mixed $\mathrm{Cu}$ oxidation states, independent of the cube size. The Cu(II)Sn(II)5 nanoparticles have a $\mathrm{CuO}$ surface and contain crystalline $\mathrm{CuO}, \mathrm{Cu}$ and $\mathrm{Cu}_{2} \mathrm{O}$ phases. The absence of $\mathrm{Sn}$ species in the final samples is due to the conditions of the synthesis. The $\mathrm{pH}$ value of the final solution at the end of the synthesis is determined to be about 12.5 at room temperature. At such high $\mathrm{pH}$, Sn element can be stabilized as $\mathrm{HSnO}_{2}{ }^{-}$and as $\mathrm{SnO}_{3}{ }^{2-}\left(\mathrm{HSnO}_{2}{ }^{-} / \mathrm{Sn}\right.$, $-0.79 \mathrm{~V} ; \mathrm{SnO}_{3}{ }^{2-} / \mathrm{HSnO}_{2}{ }^{-},-0.69 \mathrm{~V}$ versus $\mathrm{SHE}$ ) [36]. These anions are soluble in $\mathrm{H}_{2} \mathrm{O}$ or $\mathrm{H}_{2} \mathrm{O} / \mathrm{EG}$ and therefore are removed during washing.

\section{$\mathrm{CO}_{2} \mathrm{RR}$ and product analysis on the $\mathrm{Cu}-$ based electrodes}

In order to investigate the performance of various electrodes for the $\mathrm{CO}_{2} \mathrm{RR}, \mathrm{CA}$ measurements were carried out in a three-electrode two-compartment cell. The concentrations of $\mathrm{H}_{2}$ and $\mathrm{CO}$ were determined by $\mu \mathrm{GC}$ every 3-4 min. Liquid products were analyzed by HPLC at the end of each test. An asprepared working electrode was used for each CA measurement. The oxides in the electrodes can be reduced under negative potentials. FESEM and XRD analyses have been performed on all $\mathrm{Cu}$-based electrodes after reduction, and TEM has also been done on the reduced $\mathrm{Cu}(\mathrm{II}) \mathrm{Sn}(\mathrm{IV}) 10$ electrode.

FESEM images in Fig. 5 show a morphology change in all electrodes after reduction. In addition to the catalysts, carbon black and Nafion binder are present as well. In the case of the samples with the cubic morphology, including $\mathrm{Cu}(\mathrm{II}), \mathrm{Cu}(\mathrm{II}) \mathrm{Sn}(\mathrm{IV}) 5$ and $\mathrm{Cu}(\mathrm{II}) \operatorname{Sn}(\mathrm{IV}) 10$, as shown in Fig. 5 a, c, d, respectively, the cubic form is preserved. However, it is clear that the surface of the cubes walls becomes rough, and is composed of small particles. After reduction, the cubes maintain similar dimensions compared to the pristine samples at the $\mathrm{Cu}(\mathrm{II})$, $\mathrm{Cu}(\mathrm{II}) \mathrm{Sn}(\mathrm{IV}) 5$ and $\mathrm{Cu}(\mathrm{II}) \mathrm{Sn}(\mathrm{IV}) 10$ electrodes. In the case of the electrode $\mathrm{Cu}$ (II)Sn(II)5 (Fig. 5b), the initial particles with very smooth surface changed to particles with rough appearance, which are actually agglomerates of much smaller particles. In addition, in all reduced $\mathrm{Cu}$-based catalysts, part of the material evolved into smaller round particles. Such restructuring of the $\mathrm{Cu}$-based catalysts has been widely observed under the $\mathrm{CO}_{2} \mathrm{RR}$ conditions. PérezRamírez et al. [37] reported that the electrolysis leads to a roughening of the $\mathrm{Cu}_{2} \mathrm{O}$ catalysts, as reflected by the appearance of more defined nanometric polyhedral features on the surface of the particles. Buonsanti et al. [38] studied the morphological evolution of the $\mathrm{Cu}$ nanocubes during the $\mathrm{CO}_{2}$ electrolysis and found a potential-driven nanoclustering of the cubes. They
Figure 5 FESEM images of $\mathrm{Cu}$-based electrodes after reduction: a $\mathrm{Cu}(\mathrm{II})$;

b $\mathrm{Cu}(\mathrm{II}) \mathrm{Sn}(\mathrm{II}) 5$;

c $\mathrm{Cu}(\mathrm{II}) \mathrm{Sn}(\mathrm{IV}) 5$;

d $\mathrm{Cu}(\mathrm{II}) \operatorname{Sn}(\mathrm{IV}) 10$.
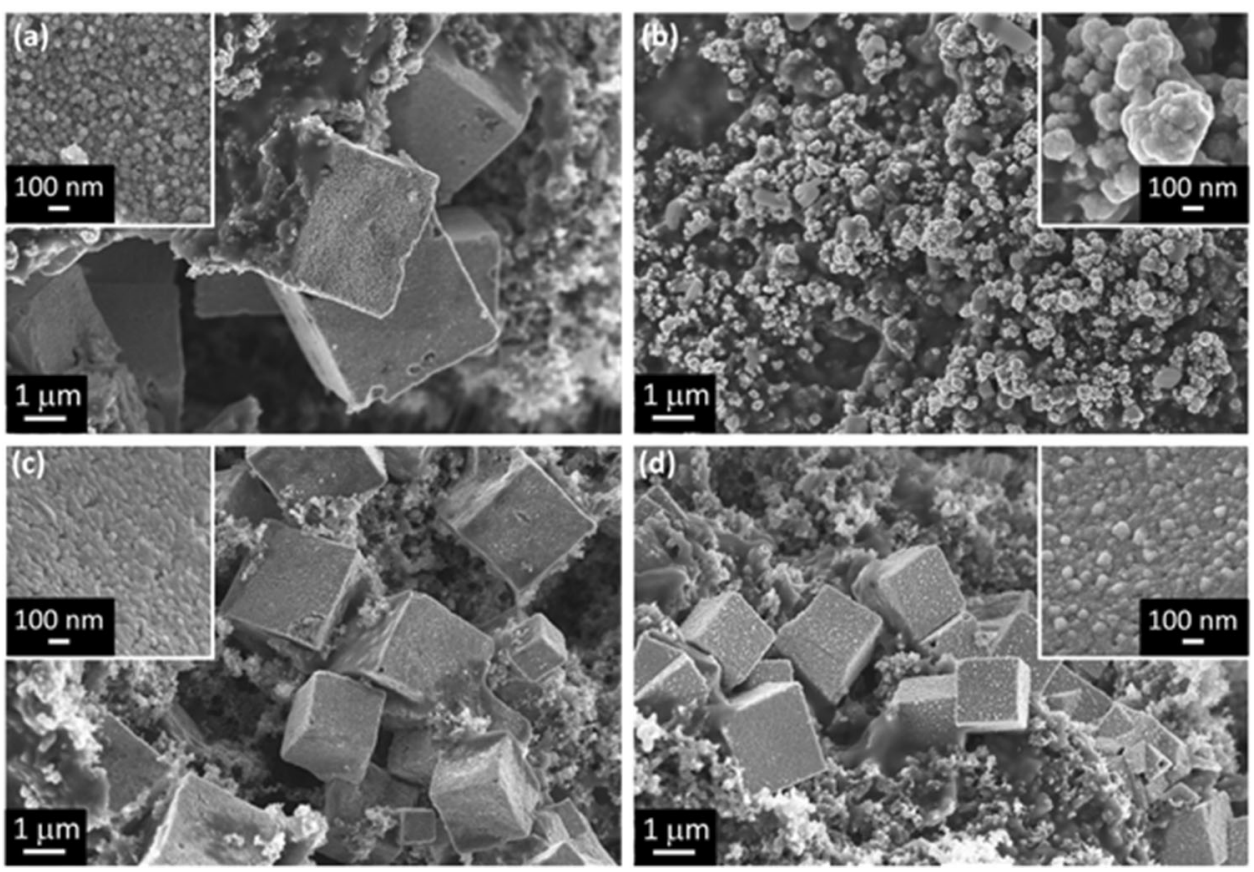


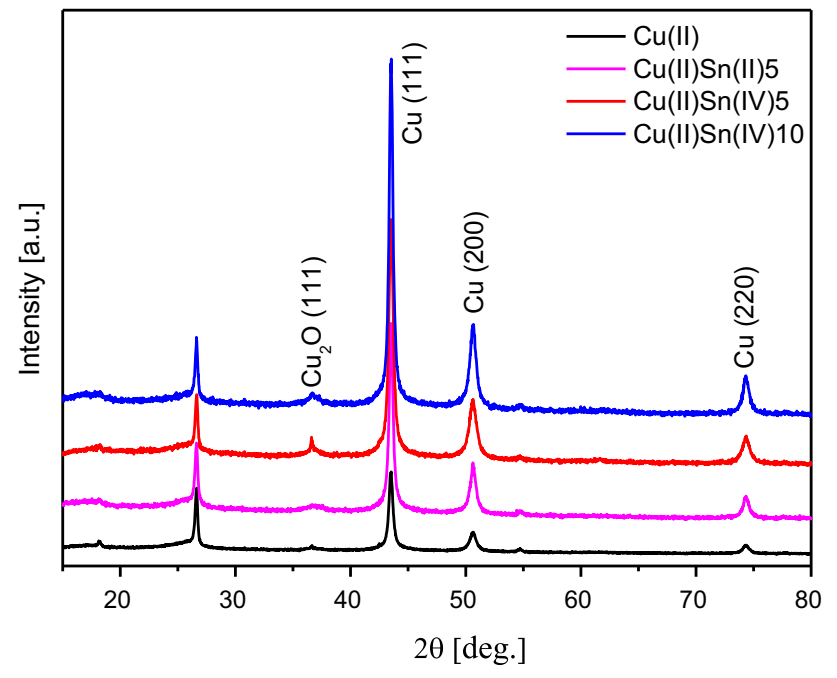

Figure 6 XRD patterns of $\mathrm{Cu}$-based electrodes after reduction.

also confirmed the negative potential applied to reduce $\mathrm{CO}_{2}$ as the main driving force for the clustering by grand-potential density functional theory calculations.

XRD patterns of the reduced electrodes are shown in Fig. 6. The peaks located at $17.9^{\circ}, 26.6^{\circ}$ and $54.7^{\circ}$ are associated with the GDL substrate (Fig. S2). Most of $\mathrm{CuO}_{x}$ is reduced into metallic $\mathrm{Cu}$ after the potential is applied, while very small amount of $\mathrm{Cu}_{2} \mathrm{O}$ is present. The crystallite size of $\mathrm{Cu}$ is estimated by applying Scherrer equation to the $\mathrm{Cu}(111)$ peak, and a similar value, in the range of tens of nanometers, has been obtained for all electrodes. This outcome confirms the nanoclustering of the electrode under applied negative potentials.

The TEM characterization of the selected Cu(II)Sn(IV)10 tested electrode was carried out in order to further elucidate the changes induced to the morphology and structure during electrochemical testing. The BF-TEM in Fig. 7a confirms that under applied negative potentials the smooth cubes walls of the untested material become rough and covered with small particles. The HRTEM of this catalyst after electrochemical testing, as shown in Fig. 7b, evidences that the small particles generated on the surface of the cubes are crystalline. This is confirmed by the FFT, in the inset, showing the ring pattern and confirming the randomly oriented crystallites. This was indexed with the lattice parameters of $\mathrm{Cu}_{2} \mathrm{O}$.

Even though crystalline $\mathrm{Cu}_{2} \mathrm{O}$ is observed from XRD and TEM on the surface of the reduced electrode, we believe that the observed $\mathrm{Cu}_{2} \mathrm{O}$ is formed due to the exposure to the air and the $\mathrm{CuO}_{x}$ is fully reduced to metallic $\mathrm{Cu}$ under the $\mathrm{CO}_{2} \mathrm{RR}$ conditions. Scott et al. [39] show that the near-surface region of a polycrystalline $\mathrm{Cu}$ electrode is fully converted to the metallic phase at approximately $+0.3 \mathrm{~V}$ by livemonitoring $\mathrm{Cu}$ and $\mathrm{Cu}_{2} \mathrm{O}$ Bragg peaks on the surface while scanning from open-circuit potential (OCP) to reduction potentials. Lum et al. [40] demonstrate that residual oxides are not present in significant amounts during $\mathrm{CO}_{2} \mathrm{RR}$ through oxygen isotopic labeling of $\mathrm{CuO}_{x}$ and secondary-ion mass spectrometry measurements. Furthermore, they show that oxidederived $\mathrm{Cu}$ can reoxidize rapidly, which could compromise the accuracy of ex situ methods for determining the true oxygen content. Hence, it is reasonable to consider that the $\mathrm{CuO}_{x}$ in the electrodes is fully reduced to $\mathrm{Cu}$ and the $\mathrm{Cu}$ is reoxidized in air during the sample preparation and transfer to XRD and TEM instruments.

To understand the electrochemical properties of the samples, EIS analysis has been carried out on the reduced $\mathrm{Cu}(\mathrm{II}), \mathrm{Cu}(\mathrm{II}) \mathrm{Sn}(\mathrm{II}) 5, \mathrm{Cu}(\mathrm{II}) \mathrm{Sn}(\mathrm{IV}) 5$ and $\mathrm{Cu}(\mathrm{II}) \mathrm{Sn}(\mathrm{IV}) 10$ electrodes. The Nyquist spectra acquired on $\mathrm{Cu}(\mathrm{II}) \mathrm{Sn}(\mathrm{IV}) 10$ sample at different potentials are reported in Fig. 8a. Similar spectra are
Figure 7 TEM

characterization of tested $\mathrm{Cu}(\mathrm{II}) \mathrm{Sn}(\mathrm{IV}) 10$ electrode: a BF-TEM and $\mathbf{b}$ HRTEM with FFT in the inset.
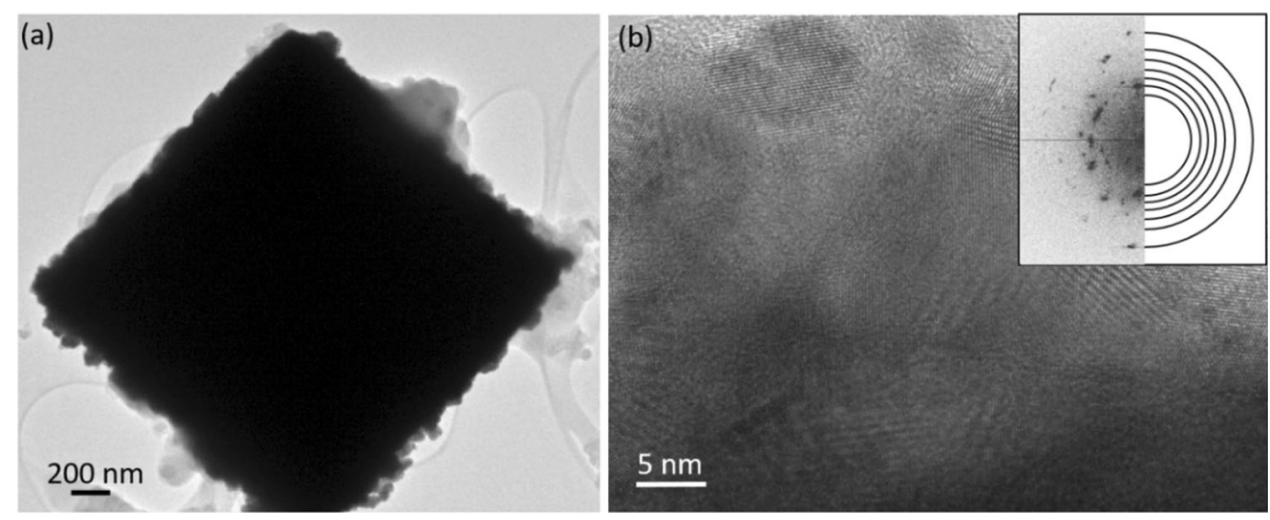


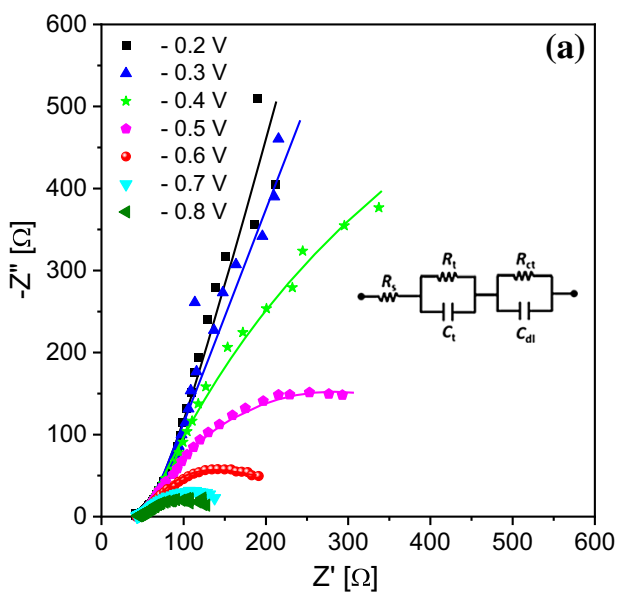

Figure 8 EIS analysis: a Nyquist plot of the impedance data acquired on $\mathrm{Cu}$ (II)Sn(IV)10 electrode in a $\mathrm{CO}_{2}$-saturated electrolyte at different potentials (the points are experimental data, and the lines are calculated using the equivalent circuit shown

obtained for the other electrodes, and all are constituted by two different features, which account for the charge transport inside the electrode (at high frequency, not dependent on the potential) and the charge transfer at the electrode/electrolyte interface (at low frequency, dependent on the potential) [41]. The total impedance decreases while negatively shifting the applied potential. The experimental data were fitted employing the equivalent circuit reported in the inset of Fig. 8a, in order to quantify the different resistance contributions to the total impedance. The simulated spectra, also shown in the same figure superimposed to the experimental curves, reveal a good match, thus witnessing the correct choice of the equivalent circuit. The charge transfer resistance $\left(R_{\mathrm{ct}}\right)$ values are reported in Fig. $8 \mathrm{~b}$ as a function of the applied potential. Apart from the exponential behavior, it can be observed that the $\mathrm{Cu}$ (II) and $\mathrm{Cu}(\mathrm{II}) \mathrm{Sn}$ (II) 5 samples are characterized by a smaller value with respect to the other two electrodes at each potential in the low potential range $(\leq-0.5 \mathrm{~V})$, while the former two displays a larger transport resistance $\left(R_{\mathrm{t}}\right)$, as shown in the inset of Fig. $8 \mathrm{~b}$.

Electrochemically active surface area (EASA) represents one of the most important properties of an electrode in the electrocatalysis. Besides cyclic voltammetry (CV), EIS is considered another powerful technique to determine the EASA of an electrode [42]. By fitting the EIS data, double-layer capacitance $\left(C_{\mathrm{dl}}\right)$ values of various electrodes are obtained and reported in Table 2. In spite of the

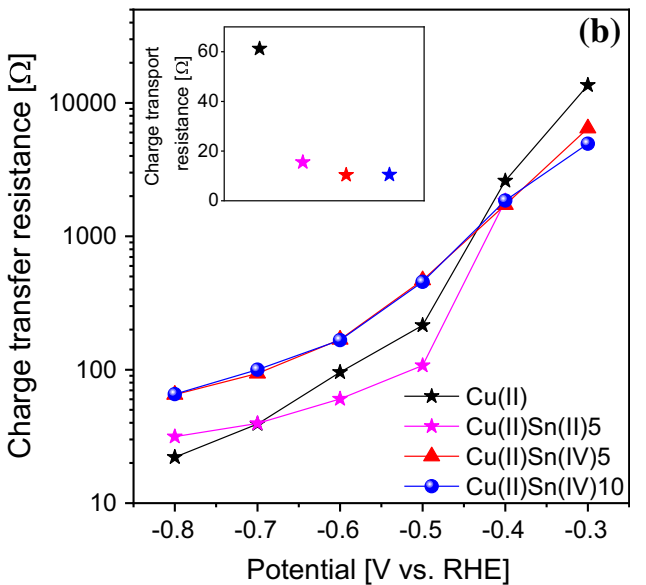

in the inset); $\mathbf{b}$ charge transfer resistance and charge transport resistance (inset of $\mathbf{b}$ ) obtained from the EIS fitting procedure at various electrodes. Electrode area: $0.25 \mathrm{~cm}^{2}$.

Table 2 Capacitance and EASA values of the electrodes

\begin{tabular}{lcc}
\hline Electrode & $C_{\mathrm{dl}}\left(\mathrm{mF} \mathrm{cm}^{-2}\right)$ & EASA $\left(\mathrm{cm}^{2}\right)$ \\
\hline $\mathrm{Cu}$ foil & 0.028 & 1 \\
$\mathrm{Cu}(\mathrm{II})$ & 18.72 & 668 \\
$\mathrm{Cu}(\mathrm{II}) \operatorname{Sn}(\mathrm{II}) 5$ & 42.35 & 1512 \\
$\mathrm{Cu}(\mathrm{II}) \operatorname{Sn}(\mathrm{IV}) 5$ & 20.24 & 722 \\
$\mathrm{Cu}(\mathrm{II}) \operatorname{Sn}(\mathrm{IV}) 10$ & 21.32 & 761 \\
\hline
\end{tabular}

complex nature of the electrode (composition of catalyst, carbon black and Nafion), we can reasonably estimate its EASA by comparing its $C_{\mathrm{dl}}$ with that of a rather flat $\mathrm{Cu}$ foil. This is because $\mathrm{Cu}_{2} \mathrm{O}$ is believed to be reduced to metallic $\mathrm{Cu}$ in the investigated potential range as discussed above and about $90 \mathrm{wt} \%$ of the catalyst layer becomes metallic $\mathrm{Cu}$. Waszczuk et al. [43] reported a $C_{\mathrm{dl}}$ value of $28 \mu \mathrm{F} \mathrm{cm} \mathrm{cm}^{-2}$ for a flat $\mathrm{Cu}$ electrode. The $C_{\mathrm{dl}}$ values of the $\mathrm{Cu}$-based electrodes are therefore divided by $28 \mu \mathrm{F} \mathrm{cm}{ }^{-2}$, resulting in the EASA of the electrodes, as listed in Table 2. The EASA values are in the following order: $\mathrm{Cu}(\mathrm{II})<$ $\mathrm{Cu}(\mathrm{II}) \mathrm{Sn}$ (IV) $5<\mathrm{Cu}$ (II)Sn(IV) $10<\mathrm{Cu}$ (II)Sn(II)5. It is believed that the high EASA values of the electrodes are derived from the surface roughening under the $\mathrm{CO}_{2} \mathrm{RR}$.

$\mathrm{CO}_{2} \mathrm{RR}$ has been performed in $0.1 \mathrm{M} \mathrm{KHCO}_{3}$ electrolyte in an H-type cell (Scheme S2). At the $\mathrm{Cu}(\mathrm{II})$ electrodes, the current densities decrease in the first $25 \mathrm{~min}$ due to the reduction of the catalysts and 
then maintain quasi-constant, as shown in Fig. S3a. The reductive current density reaches $6.2 \mathrm{~mA} \mathrm{~cm}^{-2}$ at about $-0.6 \mathrm{~V}$, and it increases while negatively shifting the applied potential $\left(9.3 \mathrm{~mA} \mathrm{~cm}^{-2}\right.$ at $-0.7 \mathrm{~V}$ and $13.6 \mathrm{~mA} \mathrm{~cm}^{-2}$ at $\left.-0.9 \mathrm{~V}\right)$. The selectivity for $\mathrm{CO}$ formation is between 20 and $30 \%$ in this potential range, while $\mathrm{H}_{2}$ is the main product at all potentials (Fig. S3b-d). The production rate of syngas $\left(\mathrm{H}_{2}+\mathrm{CO}\right)$ is about $2.6,3.5$ and $5.4 \mathrm{~mL} \mathrm{~cm}^{-2} \mathrm{~h}^{-1}$ at $-0.6 \mathrm{~V},-0.7 \mathrm{~V}$ and $-0.8 \mathrm{~V}$, respectively. Compared to the $\mathrm{Cu}$ (II) electrodes, the $\mathrm{Cu}(\mathrm{II}) \mathrm{Sn}$ (II)5 ones exhibit much lower current densities at $-0.7 \mathrm{~V}$ and $-0.8 \mathrm{~V}$ (Fig. S4a) and consequently produce smaller quantity of syngas (Fig. S4b-d). Concerning the selectivity for $\mathrm{CO}$, the $\mathrm{Cu}(\mathrm{II}) \mathrm{Sn}(\mathrm{II}) 5$ electrodes have similar FE values with respect to the $\mathrm{Cu}$ (II) ones. The performance for the $\mathrm{CO}_{2} \mathrm{RR}$ of $\mathrm{Cu}(\mathrm{II}) \mathrm{Sn}(\mathrm{IV}) 5$ and $\mathrm{Cu}(\mathrm{II}) \mathrm{Sn}(\mathrm{IV}) 10$ electrodes is shown in Fig. S5 and Fig. 9, respectively. Regarding the electrode activity, these samples show similar current densities compared to the $\mathrm{Cu}$ (II) ones at most potentials (Fig. S5a and 9a). However, the selectivity toward $\mathrm{CO}$ is significantly improved, with about $25-40 \%$ for $\mathrm{Cu}(\mathrm{II}) \mathrm{S}-$ n(IV)5 (Fig. S5b-d) and 35-50\% for Cu(II)Sn(IV)10 electrodes (Fig. 9b-d).

It is worth noting that the three electrodes containing $\mathrm{Cu}_{2} \mathrm{O}$ cubes achieve higher production rates of syngas at relatively lower overpotentials with respect to other similar studies $[44,45]$ and they also obtain comparable current densities with respect to the $\mathrm{Cu}$-based gas diffusion electrodes (GDEs) in a flow reactor at the same potentials reported by Lan et al. [46].

Figure 10a, b summarizes the CO selectivity and $\mathrm{H}_{2} / \mathrm{CO}$ ratios of the produced syngas, respectively. $\mathrm{H}_{2}$ and $\mathrm{CO}$ are the main products at the tested potentials from -0.6 to $-0.8 \mathrm{~V}$ on all electrodes. As shown in Fig. 10 a, the $\mathrm{FE}_{\mathrm{CO}}$ values are in the following order at each potential: $\mathrm{Cu}(\mathrm{II}) \mathrm{Sn}(\mathrm{II}) 5 \approx<$ $\mathrm{Cu}(\mathrm{II})<\mathrm{Cu}$ (II)Sn(IV) $5<\mathrm{Cu}$ (II)Sn(IV)10. The selectivity for $\mathrm{HCOOH}$ remains low $(\mathrm{FE}<10 \%)$, and no other liquid products are detected. Only $\mathrm{CO}$ and $\mathrm{H}_{2}$ are detected by online $\mu \mathrm{GC}$ analysis. More negative potentials $(<-0.9 \mathrm{~V})$ are not recommended for syngas production on $\mathrm{Cu}$-based electrodes, since other gas-phase products and $\mathrm{C}_{2}$ liquid products can emerge, decreasing the purity and production rate of syngas [27, 46, 47]. From Fig. 10b, the $\mathrm{H}_{2} / \mathrm{CO}$ ratio of syngas is easily tunable by using different catalysts or applying various potentials. It is interesting to note that the $\mathrm{Cu}(\mathrm{II}) \mathrm{Sn}(\mathrm{IV}) 10$ electrodes can produce syngas with a $\mathrm{H}_{2} / \mathrm{CO}$ ratio between 1 and 2 in all investigated potentials. This syngas is ideal for further synthesis of methanol [14].
Figure 9 CA measurements on the $\mathrm{Cu}(\mathrm{II}) \mathrm{Sn}(\mathrm{IV}) 10$ electrodes in $\mathrm{CO}_{2}$-saturated $0.1 \mathrm{M} \mathrm{KHCO}_{3}$ aqueous solutions at various potentials (a). The $\mathrm{FE}$ values of $\mathrm{H}_{2}$ and $\mathrm{CO}$ and the production rate of syngas at various potentials: b $-0.6 \mathrm{~V} ; \mathbf{c}-0.7 \mathrm{~V}$; d $-0.8 \mathrm{~V}$.
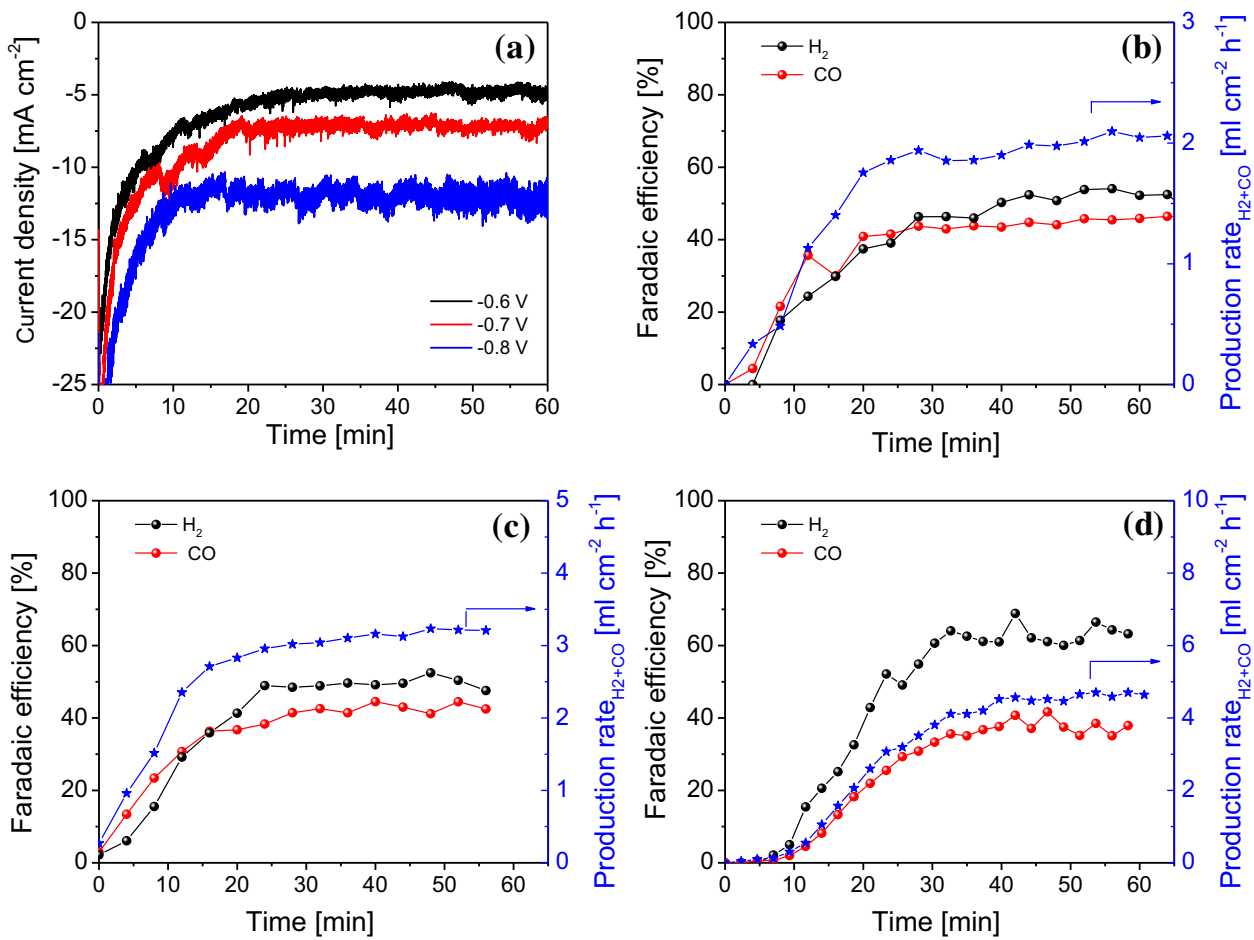
Figure $10 \mathrm{CO}_{2} \mathrm{RR}$ on various electrodes: faradaic efficiency for CO (a), the composition of the syngas (b), partial current density for $\mathrm{CO}$ formation (c) and EASA-normalized partial current density for $\mathrm{CO}$ formation (d). The solid lines shall guide the eye.
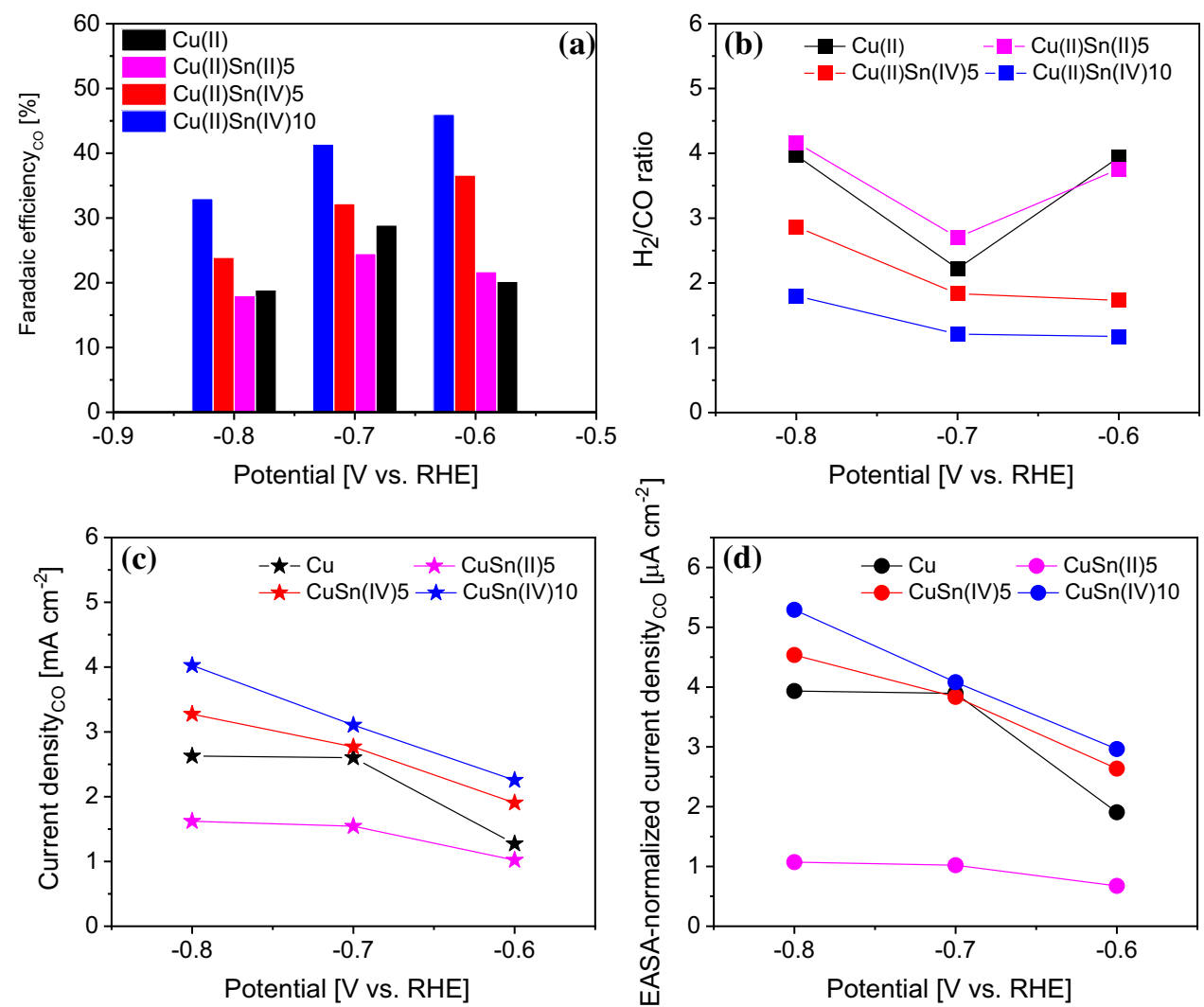

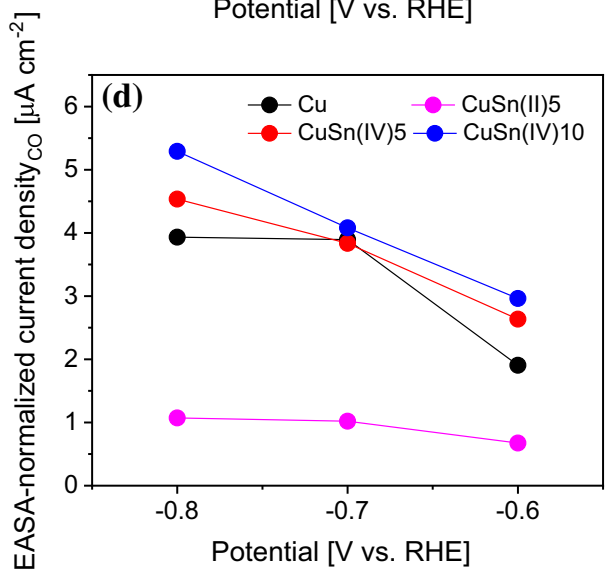

Partial current density for $\mathrm{CO}$ formation is an important parameter when evaluating the performance of an electrode for the $\mathrm{CO}_{2} \mathrm{RR}$ to $\mathrm{CO}$, since it takes into consideration both electrode activity and selectivity. The geometric partial current density for $\mathrm{CO}$ formation at various electrodes is compared in Fig. 10c. In general, the electrode reaches a higher $\mathrm{CO}$ partial current density as negatively shifting the potential. At each potential, the $\mathrm{CO}$ formation rate at the electrodes follows the trend: $\mathrm{Cu}(\mathrm{II}) \mathrm{Sn}(\mathrm{II}) 5<$ $\mathrm{Cu}$ (II) $<\mathrm{Cu}$ (II)Sn(IV) $5<\mathrm{Cu}$ (II)Sn(IV)10. Since the current normalized by geometric surface area of the electrode (electrode activity) does not reflect the actual activity of the catalyst, we calculated the current density normalized by the EASA listed in Table 2. It is necessary to point out the EASA values could undergo continuous change during the test since the surface roughening on the electrode could be sustained under the $\mathrm{CO}_{2} \mathrm{RR}$. As shown in Fig. 10d, it is clear that the $\mathrm{Cu}(\mathrm{II}) \operatorname{Sn}(\mathrm{II}) 5$ catalyst shows much lower specific current density toward $\mathrm{CO}$ formation compared to other $\mathrm{Cu}_{2} \mathrm{O}$-derived catalysts at each potential. In addition, this $\mathrm{CuO}$-derived catalyst also shows much lower specific current density for the hydrogen evolution reaction (HER), as exhibited in
Fig. S6. These outcomes indicate that the reaction sites of $\mathrm{Cu}(\mathrm{II}) \mathrm{Sn}(\mathrm{II}) 5$ catalyst could be much less active for the reduction reactions. However, it is possible that the reactions could be controlled by both kinetic and mass diffusion in the moderate-tohigh overpotential range. Since the mass diffusion effect has not been taken into considerations, the specific current density could only partially reflect the intrinsic activity of the catalyst. Since both $\mathrm{CuO}$ and $\mathrm{Cu}_{2} \mathrm{O}$ are considered to reduce to metallic $\mathrm{Cu}$ under negative potentials $[39,40]$, the reason of the different behaviors between the $\mathrm{Cu}_{2} \mathrm{O}$-derived sites and the $\mathrm{CuO}$-derived ones in this work is not clear until now. It is assumed that the difference could be related to the distinct morphologies of the $\mathrm{Cu}_{2} \mathrm{O}$ cubes and the $\mathrm{CuO}$ particles. Our previous work unveiled that not only the chemical composition is critical, but the morphology also plays a vital role in the $\mathrm{CO}_{2}$ electrolysis by affecting the mass transport at the electrode/electrolyte interface [27]. Hence, in order to study the intrinsic difference between the active sites derived from $\mathrm{Cu}_{2} \mathrm{O}$ and $\mathrm{CuO}$, it is necessary to study the $\mathrm{Cu}_{2} \mathrm{O}$ and $\mathrm{CuO}$ samples with similar morphology, which is not the scope of this work. 
Figure $11 \mathrm{CO}_{2}$ electrolysis on the $\mathrm{Cu}(\mathrm{II}) \mathrm{Sn}(\mathrm{IV}) 10$ electrode: a the dependence of $\mathrm{CO}$ partial current density on the $\left[\mathrm{HCO}_{3}{ }^{-}\right]$at logarithmic scale; $\mathbf{b}$ faradaic efficiency values for $\mathrm{CO}$ (black) and $\mathrm{H}_{2}$ (red) at various potentials in electrolyte with different $\mathrm{HCO}_{3}{ }^{-}$concentrations.
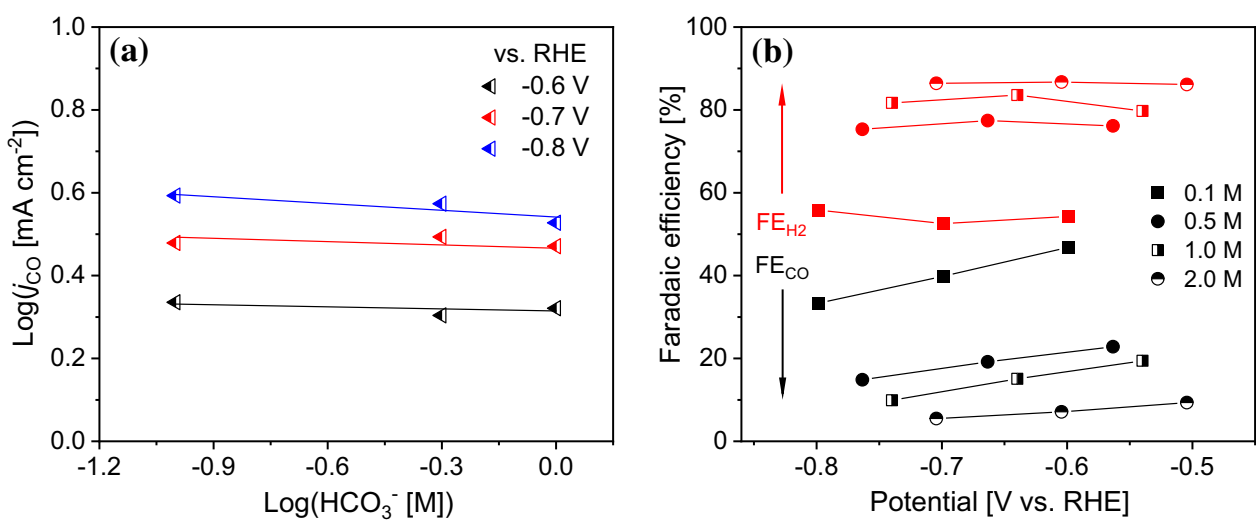

From the above analyses, all three $\mathrm{Cu}_{2} \mathrm{O}$ electrodes outperform the $\mathrm{CuO}$-rich one in terms of both syngas production rate and $\mathrm{CO}$ selectivity. By comparison of the $\mathrm{Cu}_{2} \mathrm{O}$ catalysts, decreasing cube size of the catalyst slightly increases the number of reaction sites and probably enhances the activity of the sites, resulting in improved performance for the $\mathrm{CO}_{2} \mathrm{RR}$. It is interesting to note that the three $\mathrm{Cu}_{2} \mathrm{O}$-derived catalysts have different trends in the $\mathrm{H}_{2} / \mathrm{CO}$ ratio of syngas with shifting the applied potentials (Fig. 10b). Both $\mathrm{Cu}(\mathrm{II}) \mathrm{Sn}(\mathrm{IV}) 5$ and $\mathrm{Cu}(\mathrm{II}) \mathrm{Sn}(\mathrm{IV}) 10$ electrodes exhibit a quasi-constant $\mathrm{H}_{2} / \mathrm{CO}$ ratio from -0.6 to $-0.7 \mathrm{~V}$ and a higher ratio at $-0.8 \mathrm{~V}$, while the $\mathrm{Cu}$ (II) is characterized by a minimum $\mathrm{H}_{2} / \mathrm{CO}$ ratio at $-0.7 \mathrm{~V}$. The lower $\mathrm{CO}$ selectivity of $\mathrm{Cu}(\mathrm{II})$ at $-0.6 \mathrm{~V}$ could be due to the slower nanoclustering at relatively positive potential due to its much bigger cube size compared to other $\mathrm{Cu}_{2} \mathrm{O}$ samples, creating a smaller amount of active and selective sites for the $\mathrm{CO}_{2} \mathrm{RR}$ during a determined period. The $\mathrm{Cu}(\mathrm{II}) \mathrm{S}-$ n(II)5 electrode shows a different trend, which could be attributed to the distinct behavior of its active sites for the $\mathrm{CO}_{2} \mathrm{RR}$.

The $\mathrm{Cu}(\mathrm{II}) \mathrm{Sn}(\mathrm{IV}) 10$ electrodes have further been tested in $\mathrm{KHCO}_{3}$ electrolyte with various concentrations. As shown in Fig. 11a, the rate of $\mathrm{CO}$ production is insensitive to the $\left[\mathrm{HCO}_{3}{ }^{-}\right]$at various potentials, in agreement with some recent studies on this reaction at $\mathrm{Au}$ and $\mathrm{Zn}$ electrodes [48, 49]. A zeroth-order dependence of the $\mathrm{CO}_{2} \mathrm{RR}$ to $\mathrm{CO}$ rate on the $\left[\mathrm{HCO}_{3}{ }^{-}\right]$ indicates that $\mathrm{H}_{2} \mathrm{O}$ or $\mathrm{H}_{3} \mathrm{O}^{+}$acts as the proton donor instead of $\mathrm{HCO}_{3}{ }^{-}$in the rate-limiting step of the $\mathrm{CO}_{2} \mathrm{RR}$ [50]. Figure $11 \mathrm{~b}$ shows higher $\left[\mathrm{HCO}_{3}{ }^{-}\right]$plays negative role in the $\mathrm{CO}_{2} \mathrm{RR}$ to $\mathrm{CO}$ in terms of selectivity. As increasing the $\left[\mathrm{HCO}_{3}{ }^{-}\right], \mathrm{FE}_{\mathrm{CO}}$ decreases, while $\mathrm{FE}_{\mathrm{H} 2}$ increases at each potential. This outcome is in agreement with the literature that lower bicarbonate concentrations serve to significantly enhance the $\mathrm{CO}_{2} \mathrm{RR}$ selectivity by suppressing the HER. [48].

\section{Conclusions}

An energy-efficient route has been developed to synthesize $\mathrm{Cu}$-based materials for electrochemical conversion of $\mathrm{CO}_{2}$ to syngas. By changing the precursor solutions, it is possible to obtain catalysts with different characteristics. Cubic $\mathrm{Cu}_{2} \mathrm{O}$ particles with various dimensions have been obtained and applied for the $\mathrm{CO}_{2} \mathrm{RR}$. It is revealed that the cubes undergo potential-induced crystalline and morphological modifications. These material evolutions cause dramatic surface roughing, thus creating a large number of active sites and resulting in high activity of these materials. Additionally, smaller $\mathrm{Cu}_{2} \mathrm{O}$ cubes can achieve enhanced $\mathrm{CO}$ selectivity compared to the big ones, which is likely due to the increased electrochemically active surface area. Another catalyst composed of $\mathrm{CuO} / \mathrm{Cu} / \mathrm{Cu}_{2} \mathrm{O}$ particles has been studied, and it shows worse selectivity for $\mathrm{CO}$ compared to all samples with only $\mathrm{Cu}_{2} \mathrm{O}$-based cubes. Hence, by employing different catalysts, syngas with various $\mathrm{H}_{2} / \mathrm{CO}$ ratios can be easily obtained. In particular, the catalyst with the smallest $\mathrm{Cu}_{2} \mathrm{O}$ cubes can produce syngas with a $\mathrm{H}_{2} / \mathrm{CO}$ ratio between 1 and 2 at relatively high production rates in a wide potential range. This syngas is valuable since it has an ideal $\mathrm{H}_{2} / \mathrm{CO}$ ratio for further methanol synthesis. The present work highlights the green synthesis of low-cost $\mathrm{Cu}$-based catalysts and their potential application for large-scale $\mathrm{CO}_{2}$ valorization. 


\section{Supporting information}

Scheme of a microwave-assisted solvothermal route for preparing copper-based catalysts, scheme of a three-electrode two-compartment cell, FESEM images at low magnifications of $\mathrm{Cu}(\mathrm{II}), \mathrm{Cu}(\mathrm{II}) \mathrm{Sn}(\mathrm{IV}) 5$ and $\mathrm{Cu}(\mathrm{II}) \mathrm{Sn}(\mathrm{IV}) 10$ catalysts, XRD of a GDL substrate, detailed chronoamperometric measurements at various potentials and analyses of products on $\mathrm{Cu}(\mathrm{II})$, $\mathrm{Cu}(\mathrm{II}) \mathrm{Sn}(\mathrm{II}) 5$ and $\mathrm{Cu}(\mathrm{II}) \mathrm{Sn}(\mathrm{IV}) 5$ electrodes, the current density normalized by the EASA for $\mathrm{H}_{2}$ formation at various electrodes and the XPS analysis of $\mathrm{Cu}$ and $\mathrm{Sn}$ elements on the as-prepared catalysts.

\section{Acknowledgements}

We gratefully acknowledge Dr. Filippo Drago from Istituto Italiano di Tecnologia (IIT, Genova) for performing the ICP-OES analyses.

\section{Authors' contribution}

JZ and CFP contributed to the conceptualization. SH and CFP contributed to the resources. JZ and GDM contributed to the synthesis and electrochemical measurements. MC contributed to the XPS investigation and the corresponding data analysis. KB contributed to FESEM and TEM investigations. MAF contributed to the HPLC analysis. AC contributed to the XRD investigation. AS contributed to the EIS analysis. JZ, AS and CFP contributed to the supervision of master student GDM. All authors contributed to the manuscript composition.

\section{Funding}

Open access funding provided by Istituto Italiano di Tecnologia within the CRUI-CARE Agreement.

\section{Compliance with ethical standards}

Conflicts of interest The authors declare no conflicts of interest.

Electronic supplementary material: The online version of this article (https://doi.org/10.1007/s108 53-020-05278-y) contains supplementary material, which is available to authorized users.
Open Access This article is licensed under a Creative Commons Attribution 4.0 International License, which permits use, sharing, adaptation, distribution and reproduction in any medium or format, as long as you give appropriate credit to the original author(s) and the source, provide a link to the Creative Commons licence, and indicate if changes were made. The images or other third party material in this article are included in the article's Creative Commons licence, unless indicated otherwise in a credit line to the material. If material is not included in the article's Creative Commons licence and your intended use is not permitted by statutory regulation or exceeds the permitted use, you will need to obtain permission directly from the copyright holder. To view a copy of this licence, visit http://creativecommons.org/licen ses/by $/ 4.0 /$.

\section{References}

[1] Wang Z-L, Li C, Yamauchi Y (2016) Nanostructured nonprecious metal catalysts for electrochemical reduction of carbon dioxide. Nano Today 11:373-391. https://doi.org/10. 1016/j.nantod.2016.05.007

[2] Vickers JW, Alfonso D, Kauffman DR (2017) Electrochemical carbon dioxide reduction at nanostructured gold, copper, and alloy materials. Energy Technol 5:1-22. https://d oi.org/10.1002/ente.201600580

[3] Centi G, Quadrelli EA, Perathoner S (2013) Catalysis for $\mathrm{CO}_{2}$ conversion: a key technology for rapid introduction of renewable energy in the value chain of chemical industries. Energy Environ Sci 6:1711-1731. https://doi.org/10.1039/ C3EE00056G

[4] Kondratenko EV, Mul G, Baltrusaitis J, Larrazabal GO, Perez-Ramırez J (2013) Status and perspectives of $\mathrm{CO}_{2}$ conversion into fuels and chemicals by catalytic, photocatalytic and electrocatalytic processes. Energy Environ Sci 6:3112-3135. https://doi.org/10.1039/C3EE41272E

[5] Lim RJ, Xie MS, Sk MA, Lee JM, Fisher A, Wang X, Lim $\mathrm{KH}$ (2014) A review on the electrochemical reduction of $\mathrm{CO}_{2}$ in fuel cells, metal electrodes and molecular catalysts. Catal Today 233:169-180. https://doi.org/10.1016/j.cattod.2 013.11 .037

[6] Kuhl KP, Hatsukade T, Cave ER, Abram DN, Kibsgaard J, Jaramillo TF (2014) Electrocatalytic conversion of carbon dioxide to methane and methanol on transition metal surfaces. J Am Chem Soc 136:14107-14113. https://doi.org/10. 1021/ja505791r 
[7] Zheng Y, Wang J, Yu B, Zhang W, Chen J, Qiao J, Zhang J (2017) A review of high temperature co-electrolysis of $\mathrm{H}_{2} \mathrm{O}$ and $\mathrm{CO}_{2}$ to produce sustainable fuels using solid oxide electrolysis cells (SOECs): advanced materials and technology. Chem Soc Rev 46:1427-1463. https://doi.org/10.1039/ C6CS00403B

[8] Ganesh I (2016) Electrochemical conversion of carbon dioxide into renewable fuel chemicals: the role of nanomaterials and the commercialization. Renew Sustain Energy Rev 59:1269-1297. https://doi.org/10.1016/j.rser.2016.01. 026

[9] Guzmán H, Farkhondehfal MA, Tolod KR, Hernández S, Russo N (2019) Photo/electrocatalytic hydrogen exploitation for $\mathrm{CO}_{2}$ reduction toward solar fuels production. In: Calise $\mathrm{F}$, D’Accadia MD, Santarelli M, Lanzini A, Ferrero D (eds) Solar hydrogen production. Academic Press, Cambridge, pp 365-418. https://doi.org/10.1016/B978-0-12-814853-2.0 0011-4

[10] Zhao G, Huang X, Wang X, Wang X (2017) Progress in catalyst exploration for heterogeneous $\mathrm{CO}_{2}$ reduction and utilization: a critical review. J Mater Chem A 5:21625-21649. https://doi.org/10.1039/C7TA07290B

[11] Xie H, Wang T, Liang J, Li Q, Sun S (2019) Cu-based nanocatalysts for electrochemical reduction of $\mathrm{CO}_{2}$. Nano Today 21:41-54. https://doi.org/10.1016/j.nantod.2018.05. 001

[12] Hori Y, Kikuchi K, Suzuki S (1985) Production of CO and $\mathrm{CH}_{4}$ in electrochemical reduction of $\mathrm{CO}_{2}$ at metal electrodes in aqueous hydrogencarbonate solution. Chem Lett 14:1695-1698. https://doi.org/10.1246/cl.1985.1695

[13] Yin Z, Palmore GTR, Sun S (2019) Electrochemical reduction of $\mathrm{CO}_{2}$ catalyzed by metal nanocatalysts. Trends Chem 8:739-750. https://doi.org/10.1016/j.trechm.2019.05.004

[14] Hernández S, Farkhondehfal MA, Sastre F, Makkee M, Saracco G, Russo N (2017) Syngas production from electrochemical reduction of $\mathrm{CO}_{2}$ : current status and prospective implementation. Green Chem 19:2326-2346. https://doi.org/ 10.1039/C7GC00398F

[15] Pardal T, Messias T, Sousa M, Machado ASR, Rangel CM, Nunes D, Pinto JV, Martins R, da Ponte MN (2017) Syngas production by electrochemical $\mathrm{CO}_{2}$ reduction in an ionic liquid based-electrolyte. J CO2 Util 18:62-72. https://doi. org/10.1016/j.jcou.2017.01.007

[16] Zhu W, Zhang Y-J, Zhang H, Lv H, Li Q, Michalsky R, Peterson AA, Sun S (2014) Active and selective conversion of $\mathrm{CO}_{2}$ to $\mathrm{CO}$ on ultrathin $\mathrm{Au}$ nanowires. J Am Chem Soc 136:16132-16135. https://doi.org/10.1021/ja5095099
[17] Zhang B, Zhang J (2017) Rational design of Cu-based electrocatalysts for electrochemical reduction of carbon dioxide. J Energy Chem 6:1050-1066. https://doi.org/10.10 16/j.jechem.2017.10.011

[18] Ajmal S, Yang Y, Li K, Tahir MA, Liu Y, Wang T, Bacha A, Feng Y, Deng Y, Zhang L (2019) Zinc-modified copper catalyst for efficient (photo-)electrochemical $\mathrm{CO}_{2}$ reduction with high selectivity of $\mathrm{HCOOH}$ production. J Phys Chem C 123:11555-11563. https://doi.org/10.1021/acs.jpcc.9b00119

[19] Bejtka K, Zeng J, Sacco A, Castellino M, Hernández S, Farkhondehfal MA, Savino U, Ansaloni S, Pirri CF, Chiodoni A (2019) Chainlike mesoporous $\mathrm{SnO}_{2}$ as a well-performing catalyst for electrochemical $\mathrm{CO}_{2}$ reduction. ACS Appl Energy Mater 2:3081-3091. https://doi.org/10.1021/ac saem.8b02048

[20] Zhang T, Qiu Y, Yao P, Li X, Zhang H (2019) Bi-modified $\mathrm{Zn}$ catalyst for efficient $\mathrm{CO}_{2}$ electrochemical reduction to formate. ACS Sustain Chem Eng 18:15190-15196. https://d oi.org/10.1021/acssuschemeng.9b01985

[21] Reske R, Mistry H, Behafarid F, Roldan Cuenya B, Strasser P (2014) Particle size effects in the catalytic electroreduction of $\mathrm{CO}_{2}$ on $\mathrm{Cu}$ nanoparticles. $\mathrm{J} \mathrm{Am}$ Chem Soc 136:6978-6986. https://doi.org/10.1021/ja500328k

[22] Sacco A, Zeng J, Bejtka K, Chiodoni A (2019) Modeling of gas bubble-induced mass transport in the electrochemical reduction of carbon dioxide on nanostructured electrodes. J Catal 372:39-48. https://doi.org/10.1016/j.jcat.2019.02. 016

[23] Li Y, Cui F, Ross MB, Kim D, Sun Y, Yang P (2017) Structure-sensitive $\mathrm{CO}_{2}$ electroreduction to hydrocarbons on ultrathin 5-fold twinned Copper nanowires. Nano Lett 17:1312-1317. https://doi.org/10.1021/acs.nanolett.6b05287

[24] Varela AS, Ju W, Bagger A, Franco P, Rossmeisl J, Strasser $\mathrm{P}$ (2019) Electrochemical reduction of $\mathrm{CO}_{2}$ on metal-nitrogen-doped carbon catalysts. ACS Catal 9:7270-7284. http s://doi.org/10.1021/acscatal.9b01405

[25] Hirunsit P, Soodsawang W, Limtrakul J (2015) $\mathrm{CO}_{2}$ electrochemical reduction to methane and methanol on copperbased alloys: theoretical insight. J Phys Chem C 119:8238-8249. https://doi.org/10.1021/acs.jpcc.5b01574

[26] Zeng J, Bejtka K, Ju W, Castellino M, Chiodoni A, Sacco A, Farkhondehfal MA, Hernández S, Rentsch D, Battaglia C, Pirri CF (2018) Advanced $\mathrm{Cu}-\mathrm{Sn}$ foam for selectively converting $\mathrm{CO}_{2}$ to $\mathrm{CO}$ in aqueous solution. Appl Catal B 236:475-482. https://doi.org/10.1016/j.apcatb.2018.05.056

[27] Ju W, Zeng J, Bejtka K, Ma H, Rentsch D, Castellino M, Sacco A, Pirri CF, Battaglia C (2019) Sn-decorated Cu for selective electrochemical $\mathrm{CO}_{2}$ to $\mathrm{CO}$ conversion: precision 
architecture beyond composition design. ACS Appl Energy Mater 2:867-872. https://doi.org/10.1021/acsaem.8b01944

[28] Zeng J, Bejtka K, Di Martino G, Sacco A, Castellino M, Re Fiorentin M, Risplendi F, Farkhondehfal MA, Hernández S, Cicero G, Pirri CF, Chiodoni A (2020) Microwave-assisted synthesis of copper-based electrocatalysts for converting carbon dioxide to tunable syngas. ChemElectroChem 7:229-238. https://doi.org/10.1002/celc.201901730

[29] Zeng J, Francia C, Amici J, Bodoardo S, Penazzi N (2014) Mesoporous $\mathrm{Co}_{3} \mathrm{O}_{4}$ nanocrystals as an effective electro-catalyst for highly reversible $\mathrm{Li}-\mathrm{O}_{2}$ batteries. J Power Sour 272:1003-1009. https://doi.org/10.1016/j.jpowsour.2014.09. 055

[30] Kim MH, Lim B, Lee EP, Xia Y (2018) Polyol synthesis of $\mathrm{Cu}_{2} \mathrm{O}$ nanoparticles: use of chloride to promote the formation of a cubic morphology. J Mater Chem 18:4069-4073. h ttps://doi.org/10.1039/B805913F

[31] Holder CF, Schaak RE (2019) Tutorial on powder X-ray diffraction for characterizing nanoscale materials. ACS Nano 13:7359-7365. https://doi.org/10.1021/acsnano.9b05157

[32] Kuo C-H, Huang $\mathrm{MH}$ (2008) Facile synthesis of $\mathrm{Cu}_{2} \mathrm{O}$ nanocrystals with systematic shape evolution from cubic to octahedral structures. J Phys Chem C 112:18355-18360. h ttps://doi.org/10.1021/jp8060027

[33] Soon A, Todorova M, Delley B, Stampfl C (2007) Thermodynamic stability and structure of copper oxide surfaces: a first-principles investigation. Phys Rev B 75:125420. h ttps://doi.org/10.1103/PhysRevB.75.125420

[34] Biesinger MC, Lau LWM, Gerson AR, St R, Smart C (2010) Resolving surface chemical states in XPS analysis of first row transition metals, oxides and hydroxides: $\mathrm{Sc}, \mathrm{Ti}, \mathrm{V}, \mathrm{Cu}$ and Zn. Appl Surf Sci 257:887-898. https://doi.org/10.1016/ j.apsusc. 2010.07 .086

[35] Biesinger MC (2017) Advanced analysis of copper X-ray photoelectron spectra. Surf Interface Anal 49:1325-1334. h ttps://doi.org/10.1002/sia.6239

[36] Yang T, Zhu P, Liu W, Chen L, Zhang D (2017) Recovery of tin from metal powders of waste printed circuit boards. Waste Manag 68:449-457. https://doi.org/10.1016/j.wasma n.2017.06.019

[37] Larrazábal GO, Martín AJ, Krumeich F, Hauert R, PérezRamírez J (2017) Solvothermally-prepared $\mathrm{Cu}_{2} \mathrm{O}$ electrocatalysts for $\mathrm{CO}_{2}$ reduction with tunable selectivity by the introduction of p-block elements. Chemsuschem 10:1255-1265. https://doi.org/10.1002/cssc.201601578

[38] Huang J, Hörmann N, Oveisi E, Loiudice A, De Gregorio GL, Andreussi O, Marzari N, Buonsanti R (2018) Potentialinduced nanoclustering of metallic catalysts during electrochemical $\mathrm{CO}_{2}$ reduction. Nat Commun 9:3117. https://doi. org/10.1038/s41467-018-05544-3
[39] Scott SB, Hogg TV, Landers AT, Maagaard T, Bertheussen E, Lin JC, Davis RC, Beeman JW, Higgins D, Drisdell WS, Hahn C, Mehta A, Seger B, Jaramillo TF, Chorkendorff I (2019) Absence of oxidized phases in $\mathrm{Cu}$ under $\mathrm{CO}$ reduction conditions. ACS Energy Lett 4:803-804. https://doi.org/ 10.1021/acsenergylett.9b00172

[40] Lum Y, Ager JW (2018) Stability of residual oxides in oxidederived copper catalysts for electrochemical $\mathrm{CO}_{2}$ reduction investigated with ${ }^{18} \mathrm{O}$ labeling. Angew Chem Int $\mathrm{Ed}$ 57:551-554. https://doi.org/10.1002/anie.201710590

[41] Sacco A (2018) Electrochemical impedance spectroscopy as a tool to investigate the electroreduction of carbon dioxide: a short review. J CO2 Util 27:22-31. https://doi.org/10.1016/j. jcou.2018.06.020

[42] Reid O, Saleh F, Easton E (2013) Determining electrochemically active surface area in PEM fuel cell electrodes with electrochemical impedance spectroscopy and its application to catalyst durability. Electrochim Acta 114:278-284. https://doi.org/10.1016/j.electacta.2013.10.050

[43] Waszczuk P, Zelenay P, Sobkowski J (1995) Surface interaction of benzoic acid with a copper electrode. Electrochim Acta 40:1717-1721. https://doi.org/10.1016/0013-4686(95) 00088-V

[44] Qin B, Li Y, Fu H, Wang H, Chen S, Liu Z, Peng F (2018) Electrochemical reduction of $\mathrm{CO}_{2}$ into tunable syngas production by regulating the crystal facets of earth-abundant $\mathrm{Zn}$ catalyst. ACS Appl Mater Interfaces 10:20530-20539. http s://doi.org/10.1021/acsami.8b04809

[45] Farkhondehfal MA, Hernández S, Rattalino M, Makkee M, Lamberti A, Chiodoni A, Bejtka K, Sacco A, Pirri FC, Russo N (2019) Syngas production by electrocatalytic reduction of $\mathrm{CO}_{2}$ using Ag-decorated $\mathrm{TiO}_{2}$ nanotubes. Int $\mathrm{J}$ Hydrog Energy. https://doi.org/10.1016/j.ijhydene.2019.04.180

[46] Lan Y, Gai C, Kenis PJA, Lu J (2014) Electrochemical reduction of carbon dioxide on $\mathrm{Cu} / \mathrm{CuO}$ core/shell catalysts. ChemElectroChem 1:1577-1582. https://doi.org/10.1002/ce lc. 201402182

[47] Chen K, Zhang X, Williams T, Bourgeois L, MacFarlane DR (2017) Electrochemical reduction of $\mathrm{CO}_{2}$ on core-shell $\mathrm{Cu} /$ $\mathrm{Au}$ nanostructure arrays for syngas production. Electrochim Acta 239:84-89. https://doi.org/10.1016/j.electacta.2017.04. 019

[48] Wuttig A, Yaguchi M, Motobayashi K, Osawa M, Surendranath Y (2016) Inhibited proton transfer enhances Aucatalyzed $\mathrm{CO}_{2}$-to-fuels selectivity. PNAS 113:E4585E4593. https://doi.org/10.1073/pnas.1602984113

[49] Luo W, Zhang J, Li M, Züttel A (2019) Boosting CO production in electrocatalytic $\mathrm{CO}_{2}$ reduction on highly porous Zn catalysts. ACS Catal 9:3783-3791. https://doi.org/10.10 21/acscatal.8b05109 
[50] Singh MR, Goodpaster JD, Weber AZ, Head-Gordon M, Bell AT (2017) Mechanistic insights into electrochemical reduction of $\mathrm{CO}_{2}$ over $\mathrm{Ag}$ using density functional theory and transport models. Proc Natl Acad Sci USA 114:E8812E8821. https://doi.org/10.1073/pnas.1713164114
Publisher's Note Springer Nature remains neutral with regard to jurisdictional claims in published maps and institutional affiliations. 